\title{
3 Innate lymphoid cells and disease tolerance in SARS-CoV-2 infection
}

Noah J. Silverstein ${ }^{1,2,3^{*}}$, Yetao Wang ${ }^{1,3^{*}}$, Zachary Manickas-Hill ${ }^{3,4}$, Claudia Carbone ${ }^{1}$, Ann Dauphin ${ }^{1}$, Brittany P. Boribong ${ }^{5,6,7}$, Maggie Loiselle ${ }^{5}$, Jameson Davis ${ }^{5}$, Maureen M.

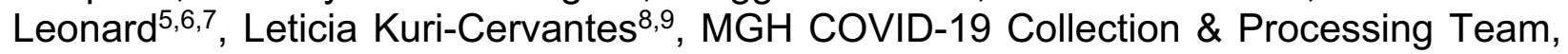
Nuala J. Meyer ${ }^{10}$, Michael R. Betts ${ }^{8,9}$, Jonathan Z. Li ${ }^{3,11}$, Bruce Walker ${ }^{3,4,12,13}, \mathrm{Xu} \mathrm{G}$. $\mathrm{Yu}^{3,4,11}$, Lael M. Yonker ${ }^{5,6,7}$, Jeremy Luban ${ }^{1,3,14,15}$

${ }^{1}$ Program in Molecular Medicine, University of Massachusetts Medical School, Worcester, MA 01605, USA

${ }^{2}$ Medical Scientist Training Program, University of Massachusetts Medical School, Worcester, MA 01605, USA

${ }^{3}$ Massachusetts Consortium on Pathogen Readiness, Boston, MA, 02115

${ }^{4}$ Ragon Institute of MGH, MIT and Harvard, Cambridge, MA 02139, USA

${ }^{5}$ Massachusetts General Hospital, Mucosal Immunology and Biology Research Center, Boston, MA, USA

${ }^{6}$ Massachusetts General Hospital, Department of Pediatrics, Boston, MA, USA

${ }^{7}$ Harvard Medical School, Boston, MA, USA

${ }^{8}$ Department of Microbiology, Perelman School of Medicine, University of Pennsylvania, Philadelphia, PA 19104, USA

Institute for Immunology, Perelman School of Medicine, University of Pennsylvania, Philadelphia, PA 19104, USA.

${ }^{10}$ Division of Pulmonary and Critical Care Medicine, Department of Medicine, University of Pennsylvania Perelman School of Medicine, Philadelphia, PA 19104, USA

${ }^{11}$ Department of Medicine, Brigham and Women's Hospital, Boston, MA 02115, USA

${ }^{12}$ Howard Hughes Medical Institute, Chevy Chase, MD 20815, USA

${ }^{13}$ Department of Biology and Institute of Medical Engineering and Science, Massachusetts Institute of Technology, Cambridge, MA

${ }^{14}$ Department of Biochemistry and Molecular Pharmacology, University of

Massachusetts Medical School, Worcester, MA 01605, USA

${ }^{15}$ Broad Institute of Harvard and MIT, 75 Ames Street, Cambridge, MA 02142, USA

${ }^{*}$ These authors contributed equally

Correspondence: yetao.wang@umassmed.edu (Y.W.); jeremy.luban@umassmed.edu (J.L.) 


\section{Abstract:}

Risk of severe COVID-19 increases with age, is greater in males, and is associated with

44 lymphopenia, but not with higher burden of SARS-CoV-2. It is unknown whether effects of age and sex on abundance of specific lymphoid subsets explain these correlations. This study found that the abundance of innate lymphoid cells (ILCs) decreases more than 7-fold over the human lifespan - T cell subsets decrease less than 2-fold - and is lower in males than in females. After accounting for effects of age and sex, ILCs, but not T cells, were lower in adults hospitalized with COVID-19, independent of lymphopenia. Among SARS-CoV-2-infected adults, the abundance of ILCs, but not of T cells, correlated inversely with odds and duration of hospitalization, and with severity of inflammation. ILCs were also uniquely decreased in pediatric COVID-19 and the numbers of these cells did not recover during follow-up. In contrast, children with MIS-C had depletion of both ILCs and $T$ cells, and both cell types increased during follow-up. In both pediatric COVID-19 and MIS-C, ILC abundance correlated inversely with inflammation. Blood ILC mRNA and phenotype tracked closely with ILCs from lung. Importantly, blood ILCs produced amphiregulin, a protein implicated in disease tolerance and tissue homeostasis, and the percentage of amphiregulin-producing ILCs was higher in females than in males. These results suggest that, by promoting disease tolerance, homeostatic ILCs decrease morbidity and mortality associated with SARS-CoV-2 infection, and that lower ILC abundance accounts for increased COVID-19 severity with age and in males. 


\section{INTRODUCTION}

63 The risk of severe COVID-19 and death in people infected with SARS-CoV-2 increases

64 with age and is greater in men than in women (Alkhouli et al., 2020; Bunders and Altfeld,

65 2020; Gupta et al., 2021; Laxminarayan et al., 2020; Mauvais-Jarvis, 2020; O’Driscoll et

al., 2020; Peckham et al., 2020; Richardson et al., 2020; Scully et al., 2020). These trends

have been observed in people infected with SARS-CoV (Chen and Subbarao, 2007;

Donnelly et al., 2003; Karlberg, 2004), or with MERS-CoV (Alghamdi et al., 2014), and in

laboratory animals challenged with SARS-CoV or SARS-CoV-2 (Channappanavar et al.,

2017; Leist et al., 2020). Yet, the mechanisms underlying these effects of age and sex on

COVID-19 morbidity and mortality remain poorly understood.

The composition and function of the human immune system changes with age and

exhibits sexual dimorphism (Darboe et al., 2020; Klein and Flanagan, 2016; Márquez et

al., 2020; Patin et al., 2018; Solana et al., 2012), with consequences for survival of

75 infection, response to vaccination, and susceptibility to autoimmune disease (Flanagan

et al., 2017; Giefing-Kröll et al., 2015; Márquez et al., 2020; Mauvais-Jarvis, 2020; Patin

77 et al., 2018; Piasecka et al., 2018). Better understanding of these effects might provide

78 clues as to why the clinical outcome of SARS-CoV-2 infection is so variable, ranging from

79 asymptomatic to lethal (Cevik et al., 2021; He et al., 2021; Jones et al., 2021; Lee et al.,

2020; Lennon et al., 2020; Ra et al., 2021; Richardson et al., 2020; Yang et al., 2021).

Survival after infection with a pathogenic virus such as SARS-CoV-2 requires not only that the immune system control and eliminate the pathogen, but that disease

83 tolerance mechanisms limit tissue damage caused by the pathogen or by host 84 inflammatory responses (Ayres, 2020a; McCarville and Ayres, 2018; Medzhitov et al., 
2012; Schneider and Ayres, 2008). Research with animal models has demonstrated that genetic and environmental factors can promote host fitness without directly inhibiting pathogen replication (Ayres, 2020a; Cumnock et al., 2018; Jhaveri et al., 2007; McCarville and Ayres, 2018; Medzhitov et al., 2012; Råberg et al., 2007; Sanchez et al., 2018; Schneider and Ayres, 2008; Wang et al., 2016). Although in most cases the underlying mechanism is unknown, some of these models suggest that subsets of innate lymphoid cells (ILCs) contribute to disease tolerance (Artis and Spits, 2015; Branzk et al., 2018; Califano et al., 2018; Diefenbach et al., 2020; McCarville and Ayres, 2018; Monticelli et al., 2015, 2011).

ILCs lack clonotypic antigen receptors but overlap developmentally and functionally with T cells. Based on expression of characteristic transcription factors and specific inducible cytokines, ILCs are classified into ILC1, ILC2, and ILC3 subsets that are analogous to $\mathrm{T}_{\mathrm{H}} 1, \mathrm{~T}_{\mathrm{H}} 2$, and $\mathrm{T}_{\mathrm{H}} 17$ cells respectively (Artis and Spits, 2015; Cherrier et al., 2018; Vivier et al., 2018; Yudanin et al., 2019). Additionally, some ILC subsets produce the epidermal growth factor family member amphiregulin (AREG) that maintains the integrity of epithelial barriers in the lung and intestine (Branzk et al., 2018; Jamieson et al., 2013; Monticelli et al., 2015, 2011), and promotes tissue repair (Artis and Spits, 2015; Cherrier et al., 2018; Klose and Artis, 2016; Rak et al., 2016). In models of influenza infection in mice, homeostatic ILCs and exogenous AREG promote lung epithelial integrity, decrease disease severity, and increase survival, without decreasing pathogen burden (Califano et al., 2018; Jamieson et al., 2013; Monticelli et al., 2011).

Little is known about disease tolerance in the context of human infectious diseases. Interestingly, SARS-CoV-2 viral load does not reliably discriminate 
symptomatic from asymptomatic infection (Cevik et al., 2021; Jones et al., 2021; Lee et influenza infection (D'Souza et al., 2019). Although the distribution of ILCs within human likely perform similar roles in maintaining tissue homeostasis and disease tolerance. determine the extent to which ILCs are decreased independently from the overall

124 Iymphopenia associated with COVID-19 (Chen et al., 2020; Huang et al., 2020; Huang and Pranata, 2020; Zhang et al., 2020; Zhao et al., 2020), or from the reported decreases 126 in other blood lymphoid cell populations (Kuri-Cervantes et al., 2020; Lucas et al., 2020;

127 Mathew et al., 2020; Mudd et al., 2020; Zheng et al., 2020). In addition, assessment of lymphoid cell abundance, in the context of a disease for which age and sex are risk factors

129 for severity, is confounded by programmed differences in lymphocyte abundance with 
medRxiv preprint doi: https://doi.org/10.1101/2021.01.14.21249839; this version posted October 11, 2021. The copyright holder for this preprint (which was not certified by peer review) is the author/funder, who has granted medRxiv a license to display the preprint in perpetuity.

131 determine whether the abundance of any blood lymphoid cell population was altered in 132 COVID-19, independent of age, sex, and global lymphopenia, and whether abundance of 133 any lymphoid cell population correlated with clinical outcome in SARS-CoV-2 infection. 


\section{RESULTS}

135 Characteristics of adult blood donors hospitalized for COVID-19, treated for COVID-

\section{9 as outpatients, or SARS-CoV-2-uninfected controls}

137 The first group of blood donors in this study included SARS-CoV-2-infected adults 138 hospitalized for severe COVID-19 $(\mathrm{N}=40)$, among whom $33(82.5 \%)$ were admitted to 139 the ICU, $32(80 \%)$ required intubation with mechanical ventilation, and 7 (17.5\%) died 140 (Table 1). This group had a mean age of 57.6 (range 24 to 83 ) and $60 \%$ were males. The second group consisted of adults infected with SARS-CoV-2 who were treated for COVID-

14219 as outpatients $(\mathrm{N}=51)$. This group had a mean age of 36.8 years (range 23-77) and 143 was $25.5 \%$ male (Table 1). Differences between these two SARS-CoV-2-infected groups, 144 in terms of median age $\left(p=5.2 \times 10^{-8}\right)$ and sex ratio $\left(p=3.7 \times 10^{-3}\right)$ (Fig. 1$)$, were consistent with the established greater risk of severe COVID-19 in older individuals and 146 in males (Alkhouli et al., 2020; Bunders and Altfeld, 2020; Gupta et al., 2021; Laxminarayan et al., 2020; Mauvais-Jarvis, 2020; O'Driscoll et al., 2020; Peckham et al., 2020; Richardson et al., 2020; Scully et al., 2020). Available information concerning

149 ethnicity and race of the blood donors was insufficient for statistical comparisons among the groups (Supplementary Table S1). Finally, 86 adults who donated blood prior to the SARS-CoV-2 outbreak, or who were screened at a blood donation center, were included as controls for SARS-CoV-2 infection. The age of this group spanned the range of the two groups of SARS-CoV-2-infected people (mean age 50.9; range 23 to 79), and the percentage of males $(55.8 \%)$ was similar to that of the group hospitalized for COVID-19 (Table 1 and Fig. 1). 


\section{Table 1: Demographic and Clinical Characteristics of Adult Blood Donor Groups}

\section{Characteristic}

\section{Healthy Control Hospitalized Outpatient}

\begin{tabular}{|c|c|c|c|}
\hline 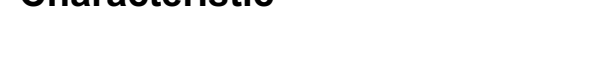 & $N=86$ & $N=40$ & \\
\hline Mean age (range) - years & $50.9(23-79)$ & $57.6(24-83)$ & $36.8(23-77)$ \\
\hline \multicolumn{4}{|l|}{ Sex - number (\%) } \\
\hline Male & $48(55.8)$ & $24(60)$ & $13(25.5)$ \\
\hline Female & $38(44.2)$ & $16(40)$ & $38(74.5)$ \\
\hline $\begin{array}{l}\text { Mean symptom duration at sample } \\
\text { collection (range) - days }\end{array}$ & & $21.8(5-66)$ & $26.9(1-61)$ \\
\hline ICU admission - number (\%) & & $33(82.5)$ & \\
\hline $\begin{array}{l}\text { Intubation with mechanical } \\
\text { ventilation - number (\%) }\end{array}$ & & $32(80)$ & \\
\hline Deaths - number (\%) & & $7(17.5)$ & \\
\hline $\begin{array}{l}\text { Mean time hospitalized (range) - } \\
\text { days }\end{array}$ & & $34.2(4-87)$ & \\
\hline \multicolumn{4}{|l|}{ Max lab value - mean (range) } \\
\hline $\mathrm{CRP}-\mathrm{mg} / \mathrm{L}$ & & $228.6(6.5-539.5)$ & \\
\hline $\mathrm{ESR}-\mathrm{mm} / \mathrm{h}$ & & $89.0(15-146)$ & \\
\hline D-dimer - (ng/mL) & & $5700(351-11923)$ & \\
\hline
\end{tabular}




\section{uninfected controls}

164 Children are less likely than adults to have severe disease when infected with SARS-

165 CoV-2 despite having viral loads as high as adults (Charles Bailey et al., 2020; Heald-

166 Sargent et al., 2020; Li et al., 2020; LoTempio et al., 2021; Lu et al., 2020; Poline et al., 167 2020; Yonker et al., 2020). Rarely, after SARS-CoV-2 clearance from the upper airways, 168 children can develop severe Multisystem Inflammatory Syndrome in Children (MIS-C), a 169 life-threatening condition distinct from COVID-19 that presents with high fevers and 170 multiorgan injury, often including coronary aneurysms, ventricular failure, or myocarditis 171 (Cheung et al., 2020; Feldstein et al., 2021, 2020; Licciardi et al., 2020; Riphagen et al., 2020; Verdoni et al., 2020; Whittaker et al., 2020).

The first cohort of pediatric blood donors in this study consisted of patients with

174 COVID-19 who were treated in hospital $(\mathrm{N}=11)$ or as outpatients $(\mathrm{N}=8)$. The second 175 cohort of pediatric blood donors was patients hospitalized for MIS-C $(N=11)$. Seventeen 176 SARS-CoV-2-uninfected pediatric blood donors constituted a control group. No significant 177 differences in age or percentage of males were detected among the pediatric COVID-19, 178 MIS-C, or pediatric control groups (Supplementary Table S2 and Fig. 1). 


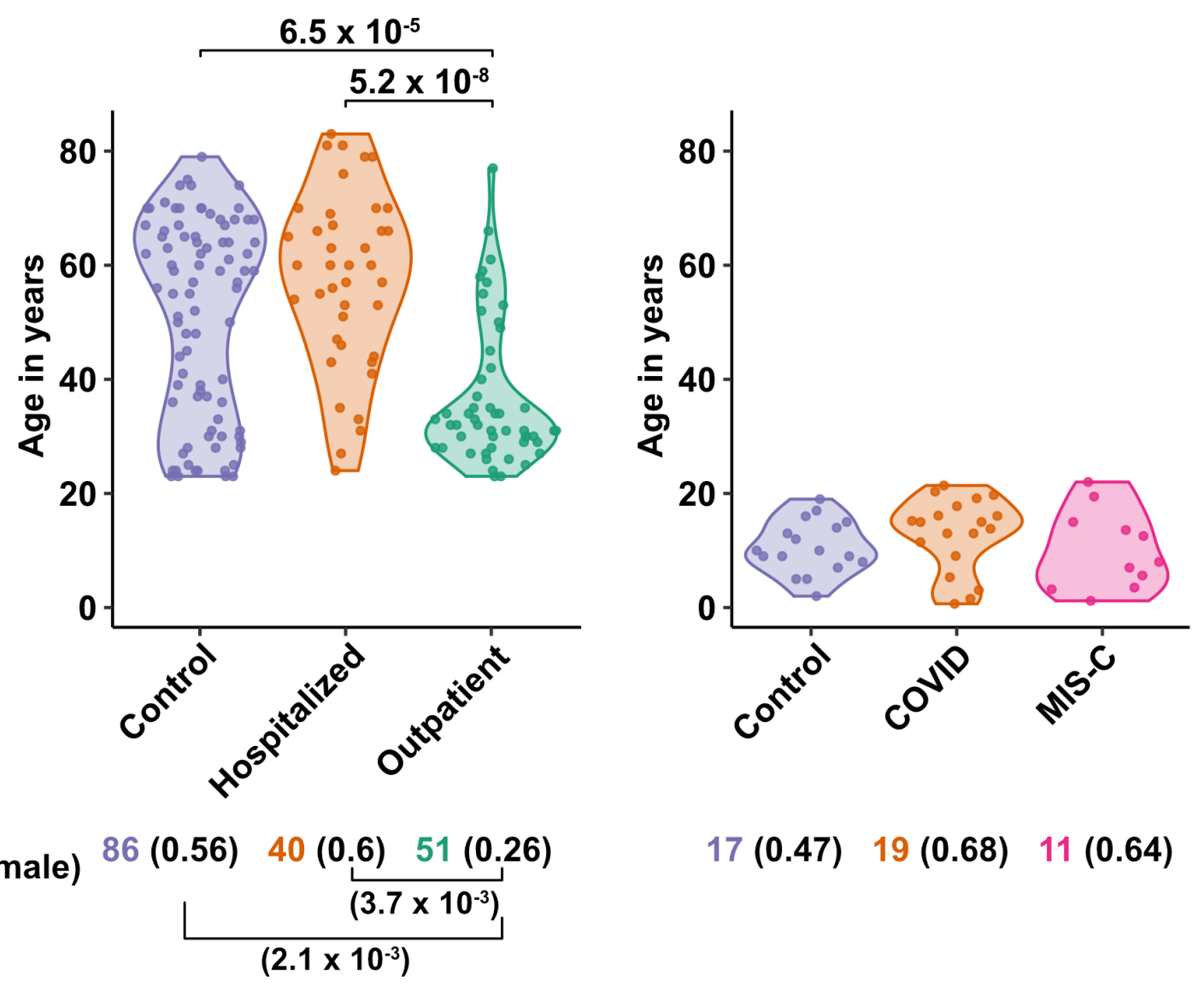

Number (fraction male)

$$
\begin{array}{|c|c|c|}
\hline(0.56) & 40(0.6) \quad 51(0.26) \\
\left(3.1 \times 10^{-3}\right)
\end{array}
$$

Fig. 1. Age and sex of control and SARS-CoV-2-infected blood donors group, for adult (left) and pediatric (right) cohorts, as indicated. P-values are from pairwise, two-sided, Wilcoxon rank-sum test for ages and Fisher's exact test for fraction

187 shown. 


\section{Blood ILC abundance decreases exponentially across the lifespan and is sexually} dimorphic

Lymphoid cell abundance in peripheral blood changes with age and is sexually dimorphic (Márquez et al., 2020; Patin et al., 2018). Previous studies reporting the effect of COVID19 on the abundance of blood lymphoid cell subsets have not fully accounted for the association of age and sex with COVID-19 severity. To isolate the effect of COVID-19 on cell abundance from effects of age and sex, PBMCs were collected from 103 SARS-CoVmales to females. Abundance of lymphoid cell types was plotted by 20 -year age groups

T cells, CD8 ${ }^{+}$T cells, ILCs, and FcyRIII (CD16)-positive NK cells. Like CD8 ${ }^{+} \mathrm{T}$ cells, NK cells kill virus-infected cells using perforin and granzyme (Artis and Spits, 2015; Cherrier et al., 2018). Additionally, by binding virus-specific immunoglobulins that target virusinfected cells for antibody-dependent cellular cytotoxicity, CD16 ${ }^{+}$NK cells link innate and acquired immunity (Anegon et al., 1988).

All cell types examined here were affected by age, but ILCs were the only subset with significant differences among all age groups, falling approximately 2-fold in median abundance every 20 years, with a greater than 7-fold decrease from the youngest to oldest age groups $\left(p=1.64 \times 10^{-11}\right)$ (Fig. 2A). This magnitude of decrease was unique to

211 ILCs and corresponded inversely with the exponential increase in COVID-19 mortality 212 with age (O’Driscoll et al., 2020) (Fig. 2C). In addition, both ILCs and CD4+ ${ }^{+}$cells were 213 less abundant in males (Fig. 2B). These findings highlight the importance of accounting 214 for effects of age and sex when assessing group differences in lymphoid cell abundance, 
medRxiv preprint doi: https://doi.org/10.1101/2021.01.14.21249839; this version posted October 11, 2021. The copyright holder for this preprint (which was not certified by peer review) is the author/funder, who has granted medRxiv a license to display the preprint in perpetuity. It is made available under a CC-BY-NC-ND 4.0 International license.

215 particularly in the context of a disease such as COVID-19 that disproportionately affects

216 older males (O'Driscoll et al., 2020). 
A

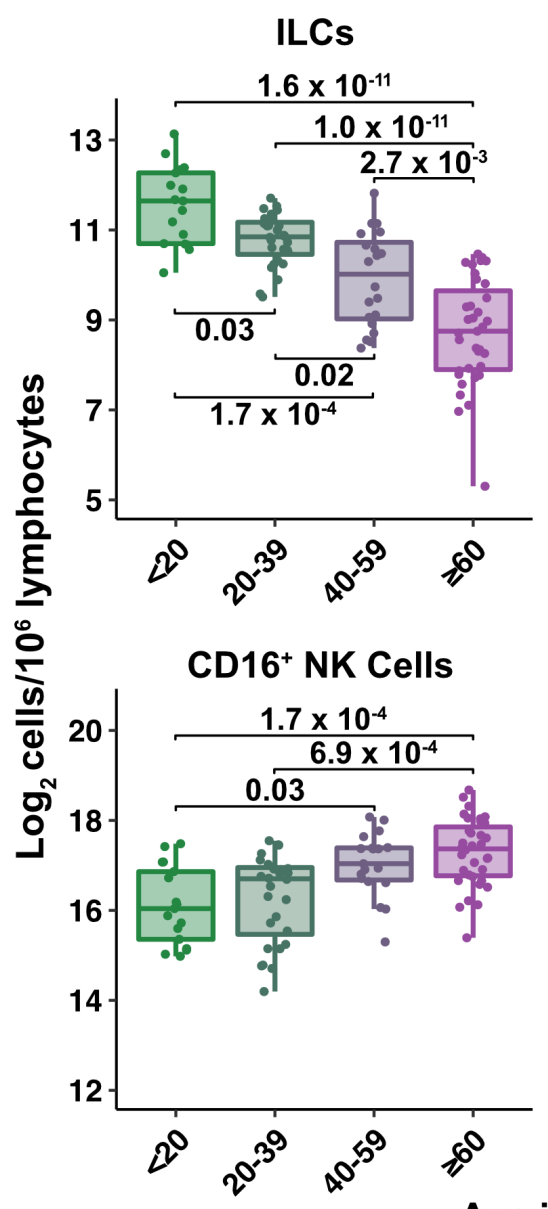

Age in years
$\mathrm{CD4}^{+} \mathrm{T}$ Cells

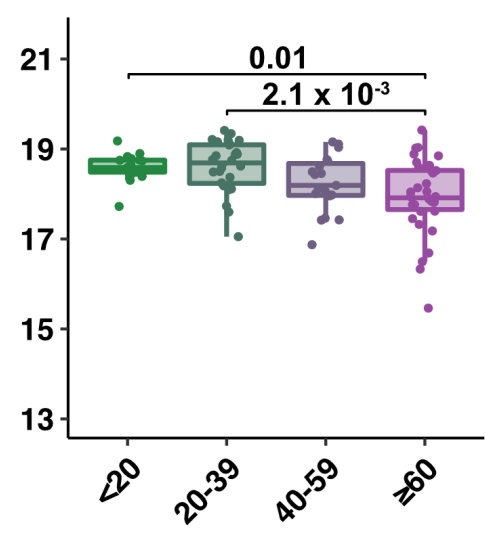

CD8 ${ }^{+}$T Cells

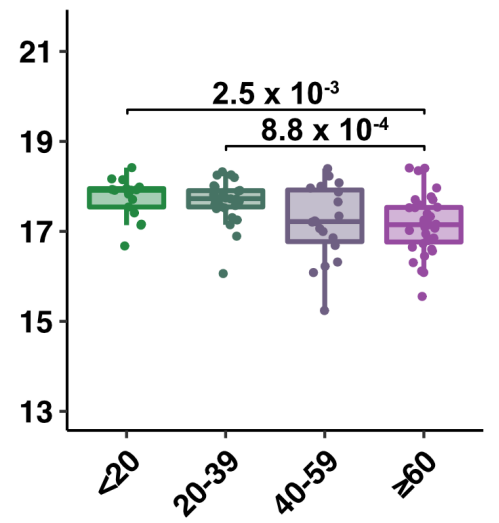

(1)

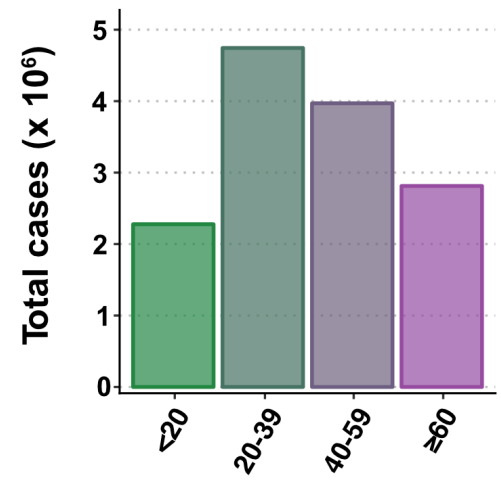

Age in years
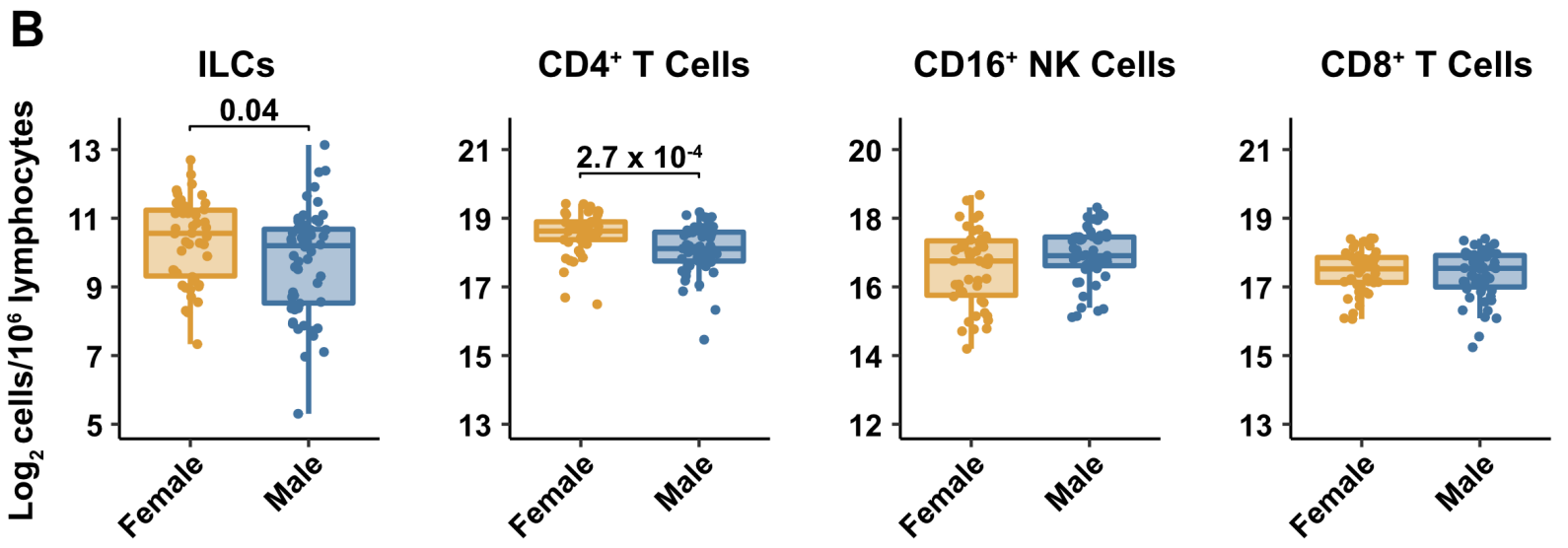

219 Fig. 2. Blood ILC abundance decreases exponentially across the lifespan mirroring 
221 (A-B) Log2 abundance per million lymphocytes of the indicated lymphoid cell populations 222 in combined pediatric and adult control data plotted by 20 -year bin or by sex, as indicated.

223 Each dot represents an individual blood donor. Boxplots represent the distribution of the 224 data with the center line drawn through the median with the upper and lower bounds of 225 the box at the 75th and 25th percentiles respectively. The upper and lower whiskers 226 extend to the largest or smallest values within $1.5 \mathrm{x}$ the interquartile range (IQR). P-values 227 are from two-sided, Wilcoxon rank-sum tests with Bonferroni correction for multiple 228 comparisons. Adjusted P-values $<0.05$ are shown.

229 (C) Case numbers and mortality rate within the indicated age ranges for cases reported 230 in the United States between Jan 1, 2020, and June 6, 2021. 
medRxiv preprint doi: https://doi.org/10.1101/2021.01.14.21249839; this version posted October 11, 2021. The copyright holder for this preprint (which was not certified by peer review) is the author/funder, who has granted medRxiv a license to display the preprint in perpetuity.

It is made available under a CC-BY-NC-ND 4.0 International license .

244 Adults hospitalized with COVID-19 have fewer total lymphocytes even after accounting for effects of age and sex

246 Severe COVID-19 is associated with lymphopenia (Chen et al., 2020; Huang et al., 2020;

247 Huang and Pranata, 2020; Zhang et al., 2020; Zhao et al., 2020) but it remains unclear if 248 this effect is due to reduction in particular lymphoid cell subpopulations, or whether this 249 effect is explained by the more advanced age and higher proportion of males among 250 people with severe COVID-19. As a first step to assess the specificity of lymphocyte 251 depletion, the effect of COVID-19 on total lymphocyte abundance was addressed with 252 multiple linear regression. After accounting for effects of age and sex, individuals 253 hospitalized with severe COVID-19 had 1.33-fold $\left(95 \% \mathrm{Cl}\right.$ : 1.49-1.19; $\left.\mathrm{p}=1.22 \times 10^{-6}\right)$ 254 fewer total lymphocytes among PBMCs than did controls (Supplementary Table S3). Lymphocyte abundance in people infected with SARS-CoV-2 who were treated as outpatients was not different from controls (Supplementary Table S3). In addition, total

257 lymphocytes decreased with age and were less abundant in males (Supplementary Table

258 S3). Subsequent analyses of lymphoid cell subsets took into account the depletion in total 259 lymphocytes associated with COVID-19 by assessing lymphoid subsets as a fraction of 260 total lymphocytes.

261 After accounting for age and sex, only innate lymphoid cells are depleted in severe 262 COVID-19

263 To determine whether there were independent associations between lymphoid cell 264 subsets and COVID-19, multiple linear regression was performed on the abundance of 265 lymphoid cell subsets, with age, sex, and group (control, hospitalized, and outpatient) as 266 independent variables. Across all three groups of adult blood donors, CD4 ${ }^{+} \mathrm{T}$ cells, CD8 ${ }^{+}$ 
267 T cells, and ILCs decreased with age, while CD16 ${ }^{+}$NK cells increased with age, and both

$268 \mathrm{CD}^{+}$T cells and ILCs were less abundant in males (Table 2 and Fig. 3A).

\section{Table 2: Change in Cell Abundance Due to Age, Sex, and COVID-19 Severity}

Fold difference $(\log 2)[ \pm 95 \% \mathrm{Cl}]$

\begin{tabular}{|c|c|c|c|c|}
\hline & $\mathrm{CD4}^{+} \mathrm{T}^{\mathrm{a}}$ & ILC $^{a}$ & $\mathrm{CD8}^{+} \mathrm{T}^{\mathrm{a}}$ & $\mathrm{CD}^{\mathrm{C}} \mathrm{N}^{+} \mathrm{NK}^{\mathrm{a}}$ \\
\hline \multirow[t]{2}{*}{$\overline{\text { Age }}$} & $-0.012^{\star * *}$ & $-0.043^{\star \star \star}$ & $-0.009^{*}$ & $0.021^{* \star \star}$ \\
\hline & {$[-0.018,-0.005]$} & {$[-0.053,-0.033]$} & {$[-0.016,-0.002]$} & {$[0.010,0.032]$} \\
\hline \multirow[t]{2}{*}{ Male } & $-0.409^{* * *}$ & $-0.334^{*}$ & -0.177 & 0.184 \\
\hline & {$[-0.618,-0.201]$} & {$[-0.659,-0.010]$} & {$[-0.406,0.051]$} & {$[-0.169,0.538]$} \\
\hline \multirow[t]{2}{*}{ Hospitalized } & 0.168 & $-0.835^{\star \star \star}$ & 0.227 & $-1.205^{\star \star \star}$ \\
\hline & {$[-0.084,0.421]$} & {$[-1.228,-0.441]$} & {$[-0.050,0.503]$} & {$[-1.633,-0.778]$} \\
\hline \multirow[t]{2}{*}{ Outpatient } & $0.332^{*}$ & -0.088 & -0.023 & $-0.522^{*}$ \\
\hline & {$[0.082,0.581]$} & {$[-0.478,0.302]$} & {$[-0.298,0.253]$} & {$[-0.948,-0.095]$} \\
\hline$\overline{R^{2}}$ & 0.275 & 0.478 & 0.070 & 0.232 \\
\hline
\end{tabular}

When effects of age and sex were held constant, adults hospitalized with COVID-

27219 had 1.78-fold fewer ILCs $\left(95 \% \mathrm{Cl}: 2.34-1.36 ; \mathrm{p}=4.55 \times 10^{-5}\right)$ and 2.31 -fold fewer

$273 \mathrm{CD}^{+} 6^{+}$natural killer $(\mathrm{NK})$ cells $\left(95 \% \mathrm{Cl}: 3.1-1.71 ; \mathrm{p}=1.04 \times 10^{-7}\right)$, as compared to controls

274 (Table 2 and Fig. 3B). Similar effects were also seen with ILC precursors (ILCP)

275 (Supplementary Fig. S1). Neither $\mathrm{CD}^{+} \mathrm{T}$ cells nor $\mathrm{CD}^{+} \mathrm{T}$ cells were depleted further

276 than expected for age and sex (Table 2 and Fig. 3B). As compared with controls, SARS-

277 CoV-2-infected adults with less severe COVID-19 who were treated as outpatients had 
278 no reduction in ILCs, but 1.44-fold fewer CD16 ${ }^{+} \mathrm{NK}$ cells $(95 \% \mathrm{Cl}: 1.93-1.07 ; p=0.018)$,

279 and 1.26-fold higher $\mathrm{CD}^{+} \mathrm{T}$ cells $\left(95 \% \mathrm{Cl}: 1.06-1.5 ; \mathrm{p}=9.59 \times 10^{-3}\right)$ (Table 2 and Fig.

$2803 \mathrm{~B}$ ). As these analyses were performed on lymphoid cell abundance normalized to total

281 lymphocyte number, it is possible that T cells were not lower in patients hospitalized with

282 COVID-19 because the amount of depletion was not in excess of the change in total

283 lymphocytes. However, the cell-type specific results remained unchanged even when the

284 analyses were repeated using the less stringent threshold of normalizing to total PBMC

285 number (Supplementary Table S4).

When data from an independent, previously published cohort (Kuri-Cervantes et

287 al., 2020) were analyzed to account for total lymphocyte abundance, age, and sex, people 288 hospitalized with acute respiratory distress syndrome due to COVID-19, had 1.7-fold 289 fewer ILCs (95\%Cl: 2.38-1.22; $p=0.002)$ than controls (Supplementary Fig. S2). Also 290 consistent with the main adult cohort studied here, ILC abundance was not significantly 291 reduced in the group of patients with less severe disease (Supplementary Fig. S2). 

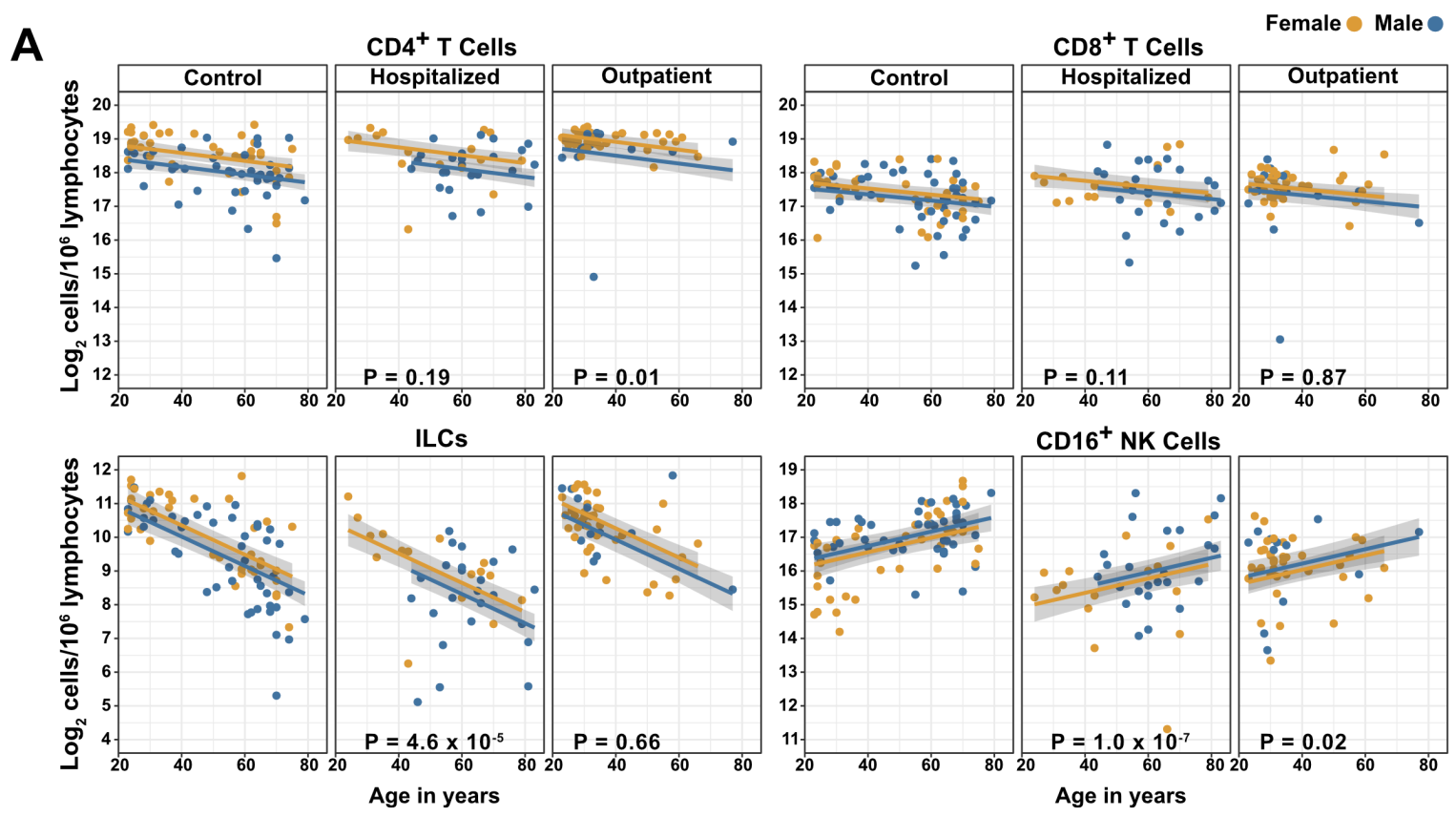

B
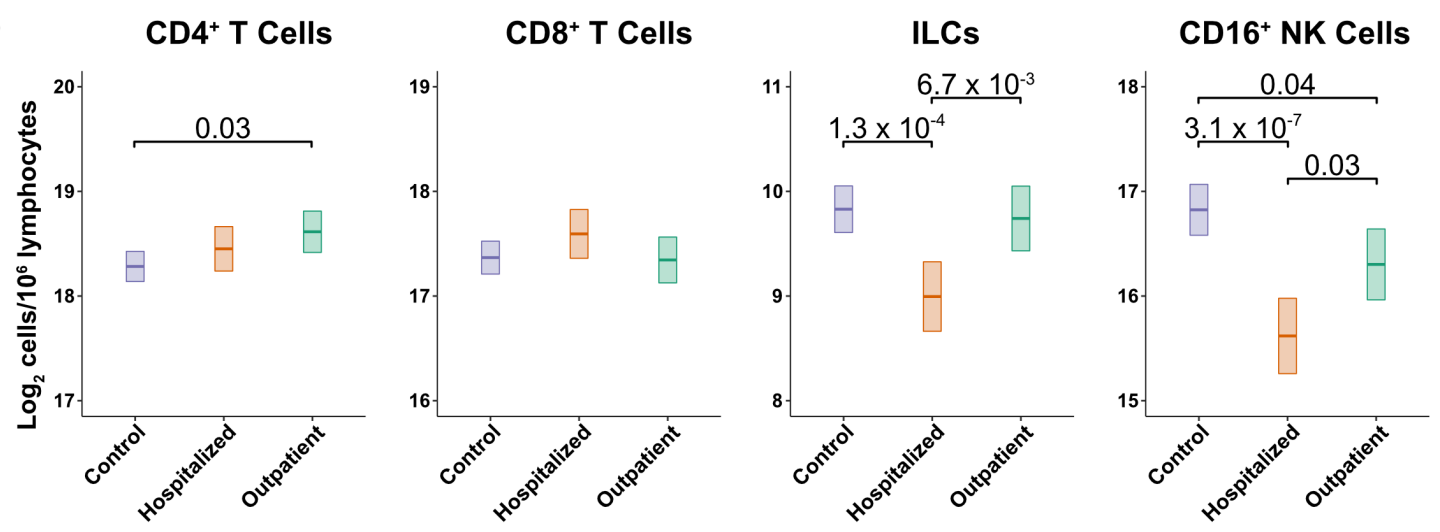

C
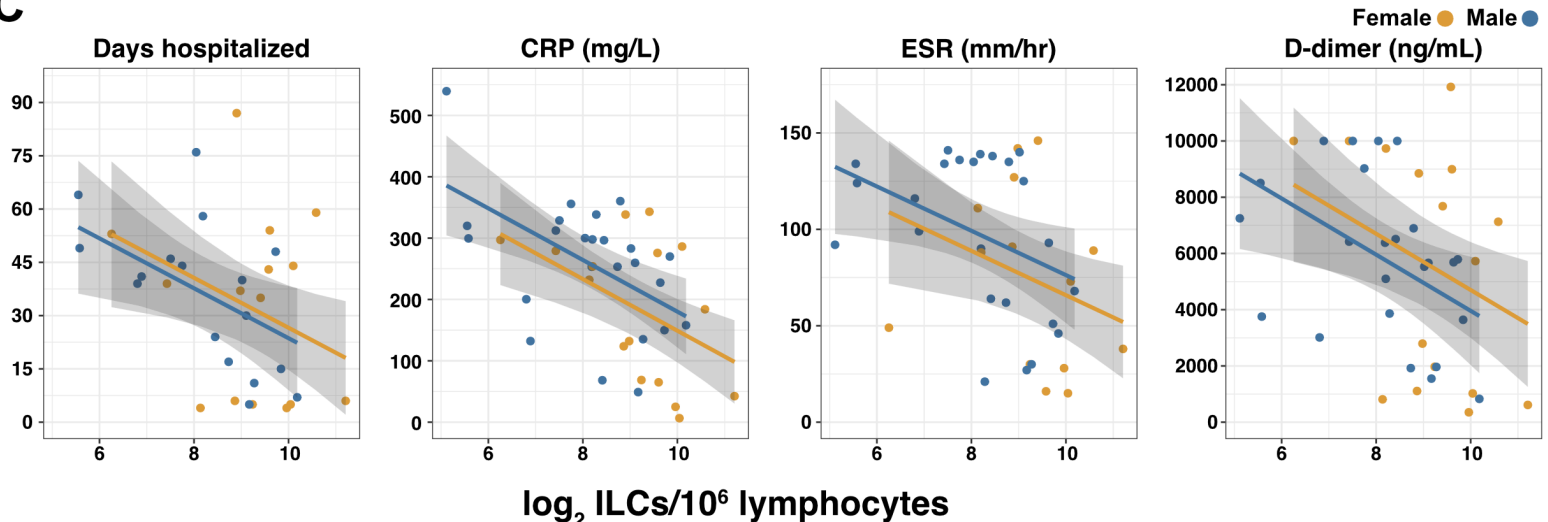

Fig. 3. Innate lymphoid cells are depleted in adults hospitalized with COVID-19 and 
(A) Effect of age (X-axis) on log2 abundance per million total lymphocytes of the indicated

297 lymphoid cell populations (Y-axis), as determined by the regression analysis in Table 2.

298 Each dot represents an individual blood donor, with yellow for female and blue for male.

299 Shading represents the $95 \% \mathrm{Cl}$. P-values are from the regression analysis for

300 comparisons to the control group.

301 (B) Log2 abundance per million lymphocytes of the indicated lymphoid cell populations, 302 shown as estimated marginal means with $95 \% \mathrm{Cl}$, generated from the multiple linear 303 regressions in Table 2, and averaged across age and sex. P-values represent pairwise 304 comparisons on the estimated marginal means, adjusted for multiple comparisons with 305 the Tukey method. Adjusted P-values $<0.05$ are shown. (C) Association of the indicated clinical parameters with log2 abundance of ILCs per million lymphoid cells. Regression lines are from simplified multiple regression models to permit visualization on a two-dimensional plane. Shading represents the $95 \% \mathrm{Cl}$. Results

310 the text. 
319 Odds of hospitalization in adults infected with SARS-CoV-2 increases with decreasing number of ILCs

321 Multiple logistic regression was used next to determine whether differences in abundance

322 of any lymphoid cell subset was associated with odds of hospitalization in people infected 323 with SARS-CoV-2. The adjusted odds ratio was calculated using lymphoid cell subset 324 abundance, age, sex, and duration of symptoms at the time of blood draw, each as 325 independent variables. Abundance of ILCs, but not of CD16 ${ }^{+}$NK cells, CD4 ${ }^{+}$T cells, or $326 \mathrm{CD}^{+} \mathrm{T}$ cells was associated with odds of hospitalization: the odds ratio for hospitalization, 327 adjusted for age, sex, and symptom duration, was $0.413(95 \% \mathrm{Cl}$ : $0.197-0.724 ; p=$ 0.00691), an increase of $58.7 \%$ for each 2 -fold decrease in ILC abundance (Table 3 ).

Table 3: Odds of Hospitalization ${ }^{a}$

\begin{tabular}{lrrr}
\hline Cell count $^{\mathbf{b}}$ & Odds Ratio $^{\mathbf{c}}$ & $\mathbf{9 5 \%}$ Confidence Interval & \multicolumn{1}{c}{ P-Value } \\
\hline $\mathrm{CD}^{+} \mathrm{T}$ & 0.501 & $0.184-1.07$ & 0.106 \\
$\mathrm{ILC}$ & 0.413 & $0.197-0.724$ & 0.007 \\
$\mathrm{CD}^{+} \mathrm{T}$ & 1.22 & $0.635-2.64$ & 0.579 \\
$\mathrm{CD} 16^{+} \mathrm{NK}$ & 0.814 & $0.53-1.21$ & 0.309
\end{tabular}

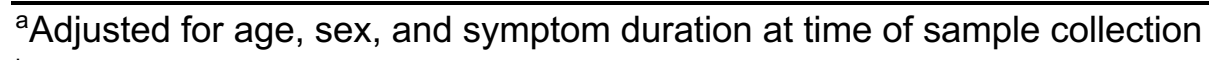
${ }^{b}$ per $10^{6}$ lymphocytes

cper 2-fold increase in cell population abundance

330 Duration of hospital stay in adults with COVID-19 increases with decreasing ILC abundance

332 The relationship between lymphoid cell abundance and duration of hospitalization was 333 assessed to determine whether the association between ILC abundance and COVID-19 
334 severity extended to clinical outcomes within the hospitalized adults. This relationship

335 was assessed with multiple linear regression, including age, sex, and cell abundance as

336 independent variables. Holding age and sex constant, abundance of ILCs, but not of

$337 \mathrm{CD} 16^{+} \mathrm{NK}$ cells, CD4 ${ }^{+} \mathrm{T}$ cells, or $\mathrm{CD}^{+} \mathrm{T}$ cells, was associated with length of time in the

338 hospital: each two-fold decrease in ILC abundance was associated with a 9.38 day 339 increase in duration of hospital stay $(95 \% \mathrm{Cl}: 15.76-3.01 ; p=0.0054)$ (Fig. $3 \mathrm{C}$ and Table $3404)$.

Table 4: Association of cell type abundance with time in hospital and laboratory values ${ }^{\mathrm{a}}$

\begin{tabular}{lllll}
\hline Cell count $^{\mathrm{b}}$ & Days hospitalized & CRP $(\mathrm{mg} / \mathrm{L})^{\mathrm{c}}$ & ESR $(\mathrm{mm} / \mathrm{h})^{\mathrm{c}}$ & D-dimer $(\mathrm{ng} / \mathrm{mL})^{\mathrm{c}}$
\end{tabular}

\begin{tabular}{l|rrrrr}
\hline CD4 $^{+} \mathbf{T}$ & -10.843 & -3.335 & -2.674 & $-1868.847^{*}$ \\
& {$[-22.511,0.825]$} & {$[-56.162,49.492]$} & {$[-23.840,18.492]$} & {$[-3375.630,-362.063]$} \\
\hline ILC & $-9.381^{* *}$ & $-46.288^{* * *}$ & $-11.035^{*}$ & $-1098.515^{*}$ \\
& {$[-15.755,-3.008]$} & {$[-71.337,-21.238]$} & {$[-21.936,-0.134]$} & {$[-1932.842,-264.188]$} \\
\hline CD8 $^{+} \mathbf{T}$ & 3.366 & 32.247 & 15.317 & 486.192 \\
& {$[-8.992,15.724]$} & {$[-16.509,81.003]$} & {$[-4.127,34.761]$} & {$[-1049.836,2022.221]$} \\
& -4.775 & -14.619 & -5.159 & -404.873
\end{tabular}

CD16 ${ }^{+}$NK

$$
[-11.251,1.701] \quad[-44.011,14.774] \quad[-16.809,6.491] \quad[-1316.261,506.516]
$$

${ }^{*} p<0.05,{ }^{* *} p<0.01,{ }^{* * *} p<0.001$

${ }^{a}$ coefficients are for each two-fold increase in cell population abundance, adjusted for age and sex $[ \pm 95 \% \mathrm{Cl}]$ ${ }^{b}$ per $10^{6}$ lymphoid cells

${ }^{\mathrm{c}}$ Maximum lab value recorded during course of hospitalization

341 ILC abundance correlates inversely with markers of inflammation in adults 342 hospitalized with COVID-19

343 To further characterize the extent to which lymphoid cell abundance predicted COVID-19 
344 severity, multiple regression with age, sex, and cell abundance, as independent variables, was performed on peak blood levels of inflammation markers indicative of COVID-19 severity: C-reactive protein (CRP) and erythrocyte sedimentation rate (ESR), and the fibrin degradation product D-dimer (Gallo Marin et al., 2020; Gupta et al., 2021; Luo et

fold decrease in ILC, but not in $\mathrm{CD} 16^{+} \mathrm{NK}$ cell, $\mathrm{CD} 4^{+} \mathrm{T}$ cell, or $\mathrm{CD}^{+} \mathrm{T}$ cell abundance,

$\left.x 1^{-4}\right)$ and $11.04 \mathrm{~mm} / \mathrm{h}$ increase in ESR (95\% Cl: 21.94-0.13; $\left.p=0.047\right)$ (Fig. 3C and

Table 4). Abundance of both ILCs and CD4 ${ }^{+} \mathrm{T}$ cells was associated with blood levels of

D-dimer, with each two-fold decrease in cell abundance associated with an increase in

D-dimer by $1098.52 \mathrm{ng} / \mathrm{mL}(95 \% \mathrm{Cl}: 1932.84-264.19 ; \mathrm{p}=0.011)$ and $1868.85 \mathrm{ng} / \mathrm{mL}$ (95\% Cl: 3375.63-362.06; $p=0.016)$, respectively (Table 4).

\section{ILCs are depleted in children and young adults with COVID-19 or MIS-C}

357 Given the decline in ILC abundance with age (Fig.s 2A and 3A, and Table 2), and the

inverse relationship between ILC abundance and disease severity in adults (Fig. 3C,

Table 3, and Table 4), it was hypothesized that children as a group have less severe

COVID-19 because ILC abundance is higher at younger ages, and that pediatric cases

with symptomatic SARS-CoV-2 infection, or with MIS-C, are accompanied by significantly

in pediatric COVID-19 or MIS-C was compared with that from pediatric controls, using 
367 already evident within the first two decades of life. In contrast, significant change over this 368 age range was not detected in the abundance of $\mathrm{CD}^{+} \mathrm{T}^{\mathrm{T}}$ cells, $\mathrm{CD}^{+} \mathrm{T}$ cells, or $\mathrm{CD} 16^{+}$ 369 NK cells (Table 5 and Fig 4A).

Among pediatric patients with COVID-19, no difference in abundance of the 371 lymphoid cell subsets was associated with hospitalization (Supplementary Table S5), so 372 all pediatric patients treated for COVID-19 were analyzed as a single group. After 373 accounting for effects of age and sex, pediatric patients with COVID-19 had 1.69-fold 374 fewer ILCs (95\%Cl: 2.73-1.04; $p=0.034)$ than controls (Fig 4A and Table 5). Neither $375 \mathrm{CD}^{+} \mathrm{T}^{-}$cells, $\mathrm{CD}^{+} \mathrm{T}$ cells, nor $\mathrm{CD}^{+} 6^{+} \mathrm{NK}$ cells were depleted in pediatric COVID-19 376 patients (Fig 4A and Table 5).

As with pediatric COVID-19, ILCs were also lower in MIS-C, with 2.14-fold fewer pediatric COVID-19, individuals with MIS-C had reduced numbers of T cells as compared with pediatric controls, with 1.6-fold fewer $\mathrm{CD}^{+}$T cells $\left(95 \% \mathrm{Cl}: 2.04-1.26 ; \mathrm{p}=3.28 \times 10^{-}\right.$ ${ }^{4}$ ) and 1.42-fold fewer CD8 ${ }^{+}$T cells (95\% Cl: 1.87-1.07; $\left.p=0.016\right)$ (Fig. 4A and Table 5). Depletion of T cells, then, distinguished MIS-C from both pediatric and adult COVID-19. Additionally, consistent with the finding in adults hospitalized with COVID-19 (Fig. 3C and 384 Table 4), after accounting for effect of group, each two-fold decrease in ILC abundance 385 in pediatric patients hospitalized with COVID-19 or MIS-C was associated with a 40.5 $386 \mathrm{mg} / \mathrm{L}$ increase in blood CRP (95\% Cl: 77.87-3.13; $\mathrm{p}=0.035)$ (Fig. 4C), and no such 387 association was detected with $\mathrm{CD}^{+} \mathrm{T}$ cells, CD8 ${ }^{+} \mathrm{T}$ cells, or CD16+ NK cells. 
Table 5: Change in Pediatric Cohort Cell Abundance Due to Age, Sex, and Group Fold difference $(\log 2)[ \pm 95 \% \mathrm{Cl}]$

\begin{tabular}{|c|c|c|c|c|}
\hline & $\mathrm{CD}^{+} \mathrm{T}^{\mathrm{a}}$ & $\mathrm{ILC}^{\mathrm{a}}$ & $\operatorname{CD8}^{+} T^{a}$ & $\mathrm{CD}^{2} 6^{+} \mathrm{NK}^{\mathrm{a}}$ \\
\hline \multirow[t]{2}{*}{$\overline{\text { Age }}$} & -0.004 & $-0.083^{\star *}$ & 0.012 & 0.004 \\
\hline & {$[-0.027,0.019]$} & {$[-0.135,-0.032]$} & {$[-0.014,0.039]$} & {$[-0.060,0.068]$} \\
\hline \multirow[t]{2}{*}{ Male } & -0.219 & -0.027 & 0.060 & -0.343 \\
\hline & {$[-0.492,0.054]$} & {$[-0.640,0.586]$} & {$[-0.249,0.370]$} & {$[-1.098,0.413]$} \\
\hline \multirow[t]{2}{*}{ COVID } & 0.018 & $-0.754^{*}$ & -0.088 & 0.416 \\
\hline & {$[-0.290,0.327]$} & {$[-1.447,-0.061]$} & {$[-0.432,0.257]$} & {$[-0.424,1.257]$} \\
\hline \multirow[t]{2}{*}{ MIS-C } & $-0.678^{* * *}$ & $-1.098^{* *}$ & $-0.503^{*}$ & -0.498 \\
\hline & {$[-1.028,-0.328]$} & {$[-1.884,-0.313]$} & {$[-0.904,-0.101]$} & {$[-1.479,0.483]$} \\
\hline$\overline{R^{2}}$ & 0.359 & 0.342 & 0.169 & 0.106 \\
\hline
\end{tabular}

The above analysis of lymphoid cell subsets in pediatric COVID-19 and MIS-C was performed in comparison to pediatric controls alone. Results were essentially unchanged when multiple linear regression was repeated with combined pediatric and adult control groups (Fig. 4B, Supplementary Fig. S3, and Supplementary Table S6).

up

397 The availability of follow-up samples in this pediatric cohort provided the opportunity to

398 assess the abundance of lymphoid subsets after recovery from illness. To this end, a 399 linear mixed model was fit to determine the change in ILC abundance from acute illness 
400 to follow-up in 10 individuals (5 COVID-19 and 5 MIS-C) for whom both acute and follow-

401 up samples were available. After accounting for effects of age, sex, and group, individuals

402 recovering from MIS-C had a 2.39-fold increase in ILC abundance $(95 \% \mathrm{Cl}: 1.49-3.81 ; p$

$403=6.6 \times 10^{-3}$ ) but there was no significant change in ILC abundance for individuals

404 recovering from COVID-19 (Fig. 4D). Both $\mathrm{CD}^{+}$and $\mathrm{CD}^{+} \mathrm{T}$ cells, which were depleted

405 in MIS-C but not in COVID-19, also increased during recovery from MIS-C and remained

406 unchanged during recovery from COVID-19 (Supplementary Fig. S4).

$407 \quad$ The relationship between time to follow-up and lymphoid cell abundance was then

408 examined for all available follow-up samples whether or not a paired sample from the

409 acute illness was available (COVID-19, N=14; MIS-C, N=7). This analysis found no 410 relationship between time to follow-up and abundance of any lymphoid subset, and that

411 individuals recovering from MIS-C had 2.28-fold more ILCs $(95 \% \mathrm{Cl}$ : 1.11-4.69; $\mathrm{p}=$ $4120.0265)$ than individuals recovering from COVID-19 (Fig. 4E). There was no difference 413 between the follow-up groups in $\mathrm{CD}^{+} \mathrm{T}$ cells, CD8 ${ }^{+} \mathrm{T}$ cells, or CD16 ${ }^{+} \mathrm{NK}$ cells (Fig. 4E).

414 Interestingly, prior to being hospitalized with MIS-C, only one of these patients had 415 COVID-19 symptoms and, despite low ILC abundance in the COVID-19 follow-up cohort, 416 only $28.6 \%$ of this group had been ill enough to require hospitalization (Supplementary 417 Table S2).

418 Differences between COVID-19 and MIS-C in regards to T cell depletion and ILC 419 recovery during follow-up indicate that the underlying processes causing lower ILC 420 abundance in these two SARS-CoV-2-associated diseases are different. 
A
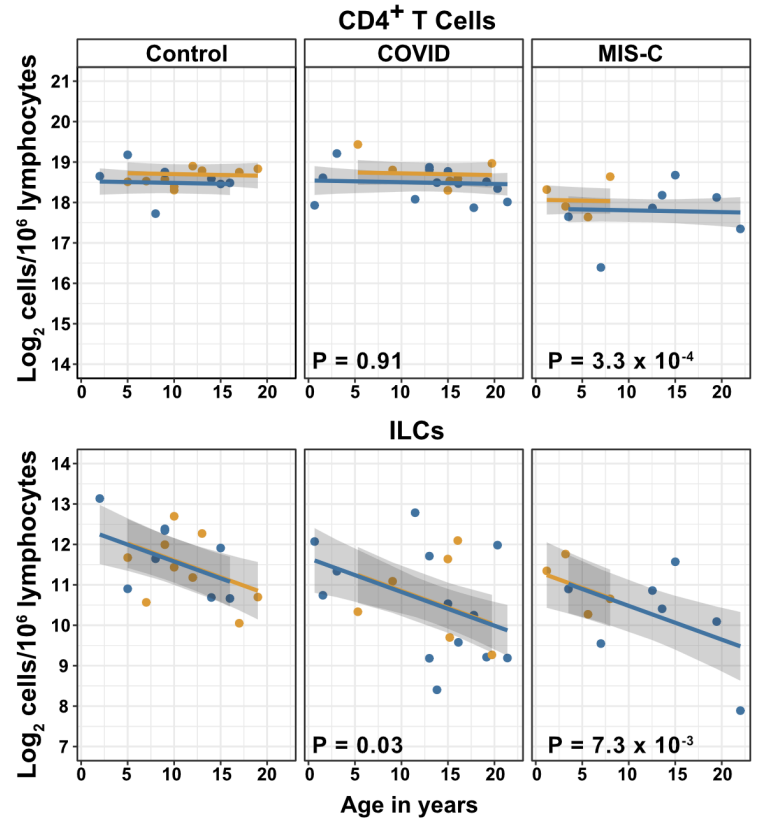

B

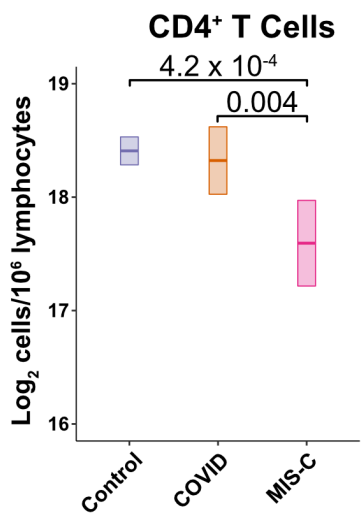

C

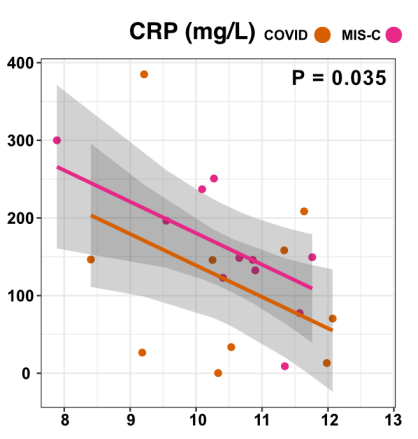

$\log _{2}$ ILCs $/ 10^{6}$ lymphocytes
CD8 $^{+} \mathrm{T}$ Cells

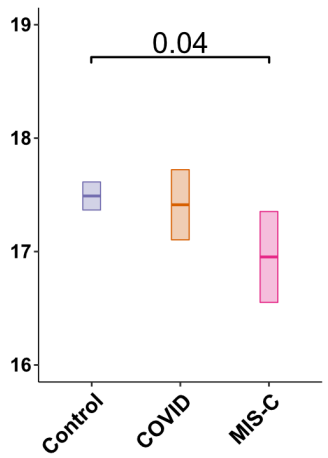

D

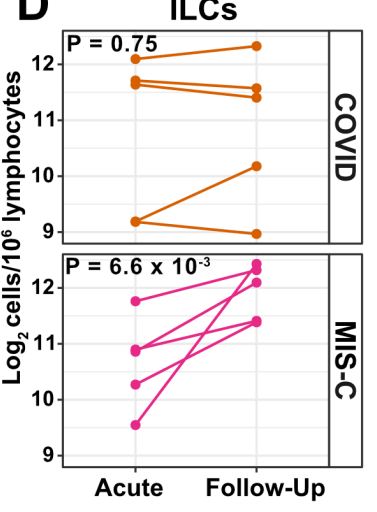

Female Male
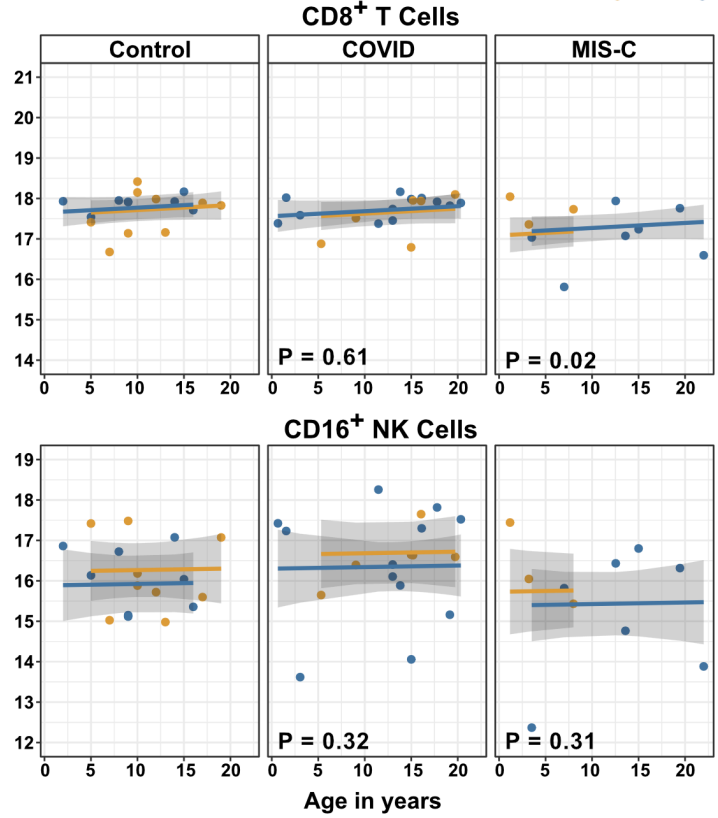

Age in years

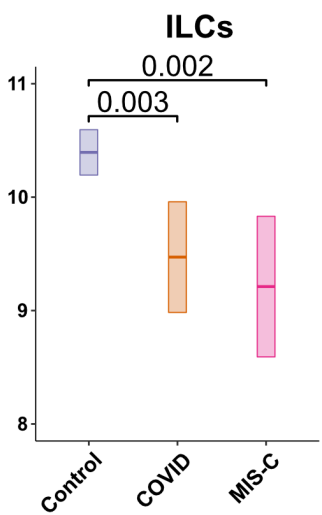

CD16 ${ }^{+}$NK Cells

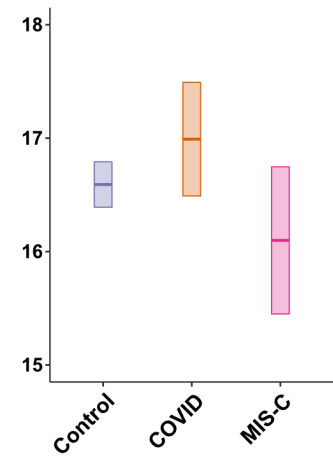

E
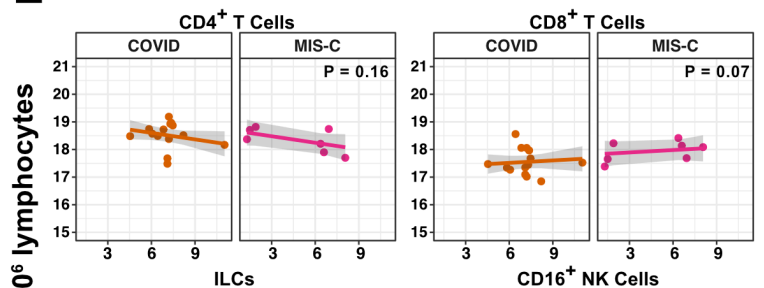

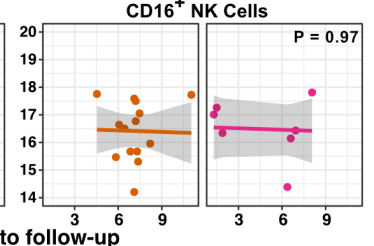


424 (A) Effect of age (X-axis) on log2 abundance per million lymphocytes of the indicated 425 lymphoid cell populations (Y-axis), as determined by the regression analysis in Table 5.

426 Each dot represents an individual blood donor, with yellow for female and blue for male.

427 Shading represents the $95 \% \mathrm{Cl}$. P-values are from the regression analysis for

428 comparisons to the control group.

429 (B) Log2 abundance per million lymphocytes of the indicated lymphoid cell populations, 430 shown as estimated marginal means with $95 \% \mathrm{Cl}$, generated from the multiple linear 431 regressions in Table S6 that included the combined pediatric and adult control data, and 432 averaged across age and sex. P-values represent pairwise comparisons on the estimated 433 marginal means, adjusted for multiple comparisons with the Tukey method. Adjusted P434 values $<0.05$ are shown.

435 (C) Association of CRP with log2 abundance of ILCs per million lymphocytes. Shading 436 represents the $95 \% \mathrm{Cl}$. Each dot represents a single blood donor, orange for COVID-19, 437 magenta for MIS-C. P-value is for the effect of ILC abundance on CRP as determined by 438 linear regression.

439 (D) Log2 ILC abundance per million lymphocytes in longitudinal pairs of samples 440 collected during acute presentation and during follow-up, from individual children with 441 COVID-19 or MIS-C. Each pair of dots connected by a line represents an individual blood 442 donor. P-values are for change in ILC abundance at follow-up, as determined with a linear 443 mixed model, adjusting for age, sex, and group, and with patient as a random effect.

444 (E) Effect of time to follow-up (X-axis) on log2 abundance per million lymphocytes of the 445 indicated lymphoid cell populations (Y-axis). P-values are for the difference between the 
medRxiv preprint doi: https://doi.org/10.1101/2021.01.14.21249839; this version posted October 11, 2021. The copyright holder for this preprint (which was not certified by peer review) is the author/funder, who has granted medRxiv a license to display the preprint in perpetuity.

It is made available under a CC-BY-NC-ND 4.0 International license .

446 COVID-19 and MIS-C follow-up groups, independent of time to follow-up as determined

447 by linear regression. Shading represents the $95 \% \mathrm{Cl}$.

448 Blood ILCs resemble homeostatic ILCs isolated from lung

449 In response to the observations described above regarding abundance of blood ILCs and

450 severity of COVID-19 attempts were made to extend these studies to lung ILCs. It was

451 not possible to obtain lung samples from people with COVID-19. However, ILCs circulate

452 from tissues to the bloodstream in lymphatic drainage via the thoracic duct (Buggert et

453 al., 2020) suggesting that measurement of blood ILCs could provide a surrogate for

454 assessment of tissue-resident ILCs, including those from the lung. Furthermore, reduction

455 in blood ILCs in people living with HIV-1 infection is paralleled by decreased ILC numbers

456 within the lamina propria of the colon (Wang et al., 2020), and so the lower abundance of

457 blood ILCs associated with severe COVID-19 might be paralleled by decreased

458 abundance of homeostatic ILCs in the lung.

459 Given the inability to assess lung samples from people with COVID-19, RNA

460 sequencing (RNA-Seq) was performed on blood ILCs from nine healthy controls and

461 these data were compared to previously published RNA-Seq profiles of ILCs sorted from

462 lung, spleen, and intestine (Ardain et al., 2019; Yudanin et al., 2019). Unbiased principal

463 component analysis demonstrated overlap of blood ILCs with lung ILCs and clear

464 separation from ILCs of jejunum or spleen (Fig. 5A). 355 genes were consistently

465 differentially expressed (fold-change $>1.5$, padj $<0.01$ ) when either blood or lung ILCs

466 were compared to ILCs from the other tissues (Fig. 5B,C). Gene ontology analysis

467 demonstrated enrichment for terms associated with type 2 immunity (Supplementary

468 Table S7). Genes significantly higher in both blood and lung ILCs included the ILC2- 
medRxiv preprint doi: https://doi.org/10.1101/2021.01.14.21249839; this version posted October 11, 2021. The copyright holder for this preprint (which was not certified by peer review) is the author/funder, who has granted medRxiv a license to display the preprint in perpetuity. It is made available under a CC-BY-NC-ND 4.0 International license.

469 defining genes GATA3 and PTGDR2 (CRTH2), as well as other genes important for ILC

470 development such as TCF7 (Yang et al., 2013) (Fig. 5B,C). As confirmation of the RNA

471 signature, TCF7- and CRTH2-encoded proteins were detected in blood ILCs by flow

472 cytometry (Fig. 6A). 

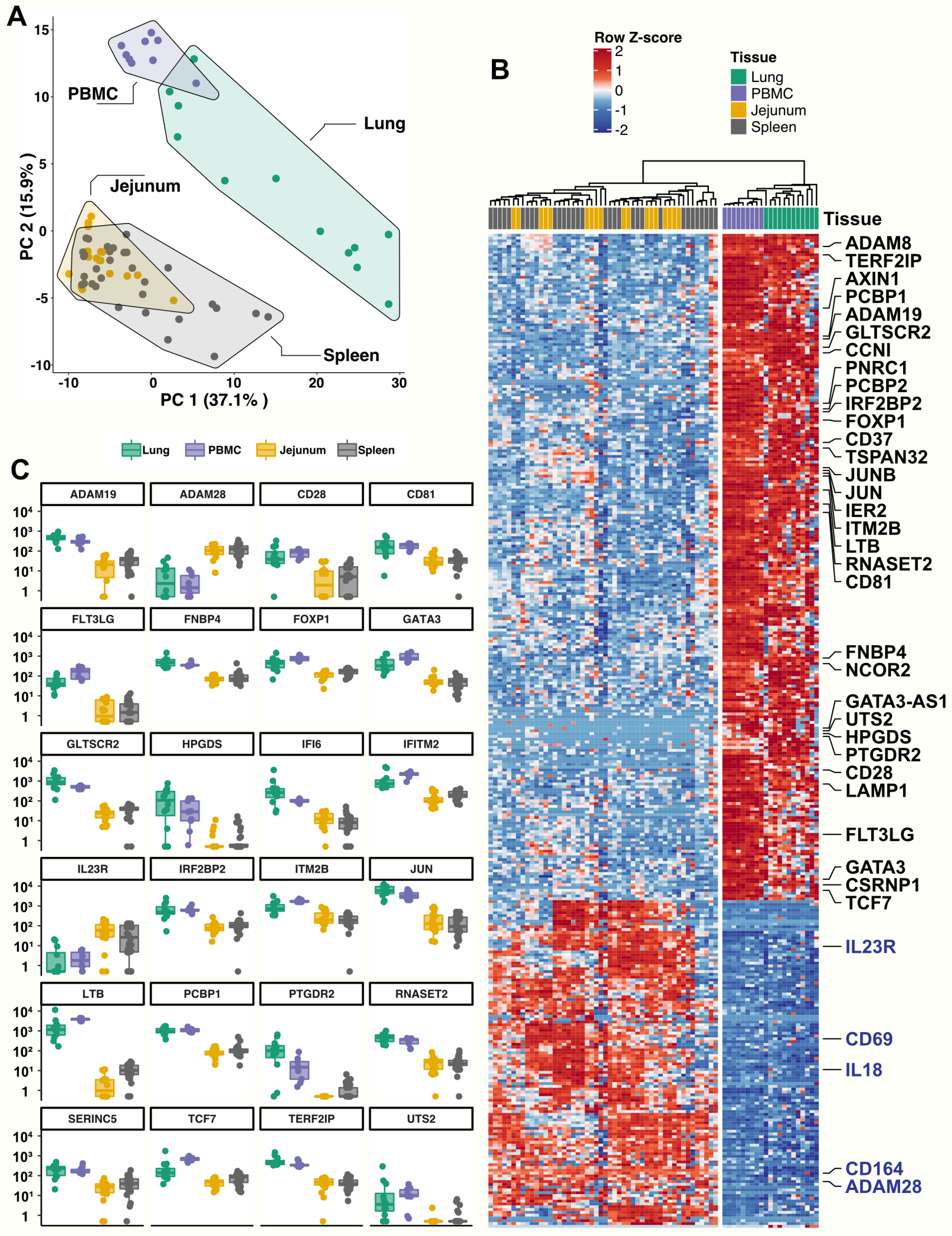

474 Fig. 5. Blood ILCs are transcriptionally similar to lung ILCs 
475 RNA-seq of ILCs sorted from blood of 9 SARS-CoV-2-uninfected controls in comparison

476 to RNA-seq data of ILCs sorted from jejunum, lung, and spleen.

477 (A) PCA plot of first two principal components calculated from the top 250 most variable genes across all samples. Each dot represents an individual sample with blue for ILCs

479 sorted from blood, green for lung, yellow for jejunum, and grey for spleen.

480 (B) Heatmap of 355 genes differentially expressed (fold-change $>1.5$, padj $<0.01$ as 481 determined with DESeq2) between either blood or lung ILCs and ILCs from the other 482 tissues.

483 (C) Select genes from (B) plotted as deseq2 normalized counts. Each dot represents an 484 individual sample with blue for ILCs sorted from blood, green for lung, yellow for jejunum, 485 and grey for spleen. Boxplots represent the distribution of the data with the center line 486 drawn through the median with the upper and lower bounds of the box at the 75th and 487 25th percentiles respectively. The upper and lower whiskers extend to the largest or 488 smallest values within $1.5 \mathrm{x}$ the interquartile range (IQR). 


\section{Blood ILCs are functional ILC2s capable of producing AREG}

498 To assess the function of blood ILCs, PBMCs were stimulated with PMA and ionomycin, 499 and assayed by flow cytometry for production of IL-13 after intracellular cytokine staining 500 and gating on ILCs. IL-13 was detected in the stimulated ILC population (Fig. 6B), 501 demonstrating that the majority of blood ILCs function as ILC2s. Additionally, the blood 502 ILCs produced amphiregulin (Fig. 6B), a protein implicated in the promotion of disease 503 tolerance by ILCs in animal models (Branzk et al., 2018; Diefenbach et al., 2020; 504 Jamieson et al., 2013; McCarville and Ayres, 2018; Monticelli et al., 2015, 2011).

Females have a higher fraction of amphiregulin-producing blood ILCs than do males

507 Given the role AREG-producing ILCs play in maintaining disease tolerance in animal 508 models (Branzk et al., 2018; Diefenbach et al., 2020; McCarville and Ayres, 2018;

509 Monticelli et al., 2015, 2011), sex differences in the functional capability of these ILCs 510 could contribute to the greater risk for severe COVID-19 in males (O'Driscoll et al., 511 2020). To address this hypothesis, ILCs isolated from peripheral blood of controls were

512 stimulated with PMA and ionomycin, and assayed by flow cytometry for AREG

513 production. Consistent with the apparently lower disease tolerance in males, males had

514 a lower median fraction of $\mathrm{AREG}^{+}$ILCs than did females $(P=0.018)$ (Fig. 6C). This

515 difference was also reflected in a significantly lower AREG Mean Fluorescent Intensity

516 (MFI) in males, and neither fraction of $\mathrm{AREG}^{+}$ILCs nor AREG MFI was affected by age

517 (Supplementary Fig. S5). 


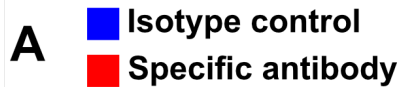

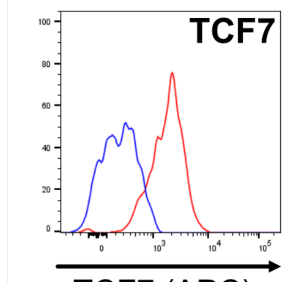

B
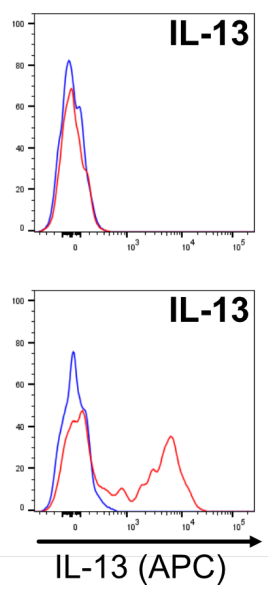
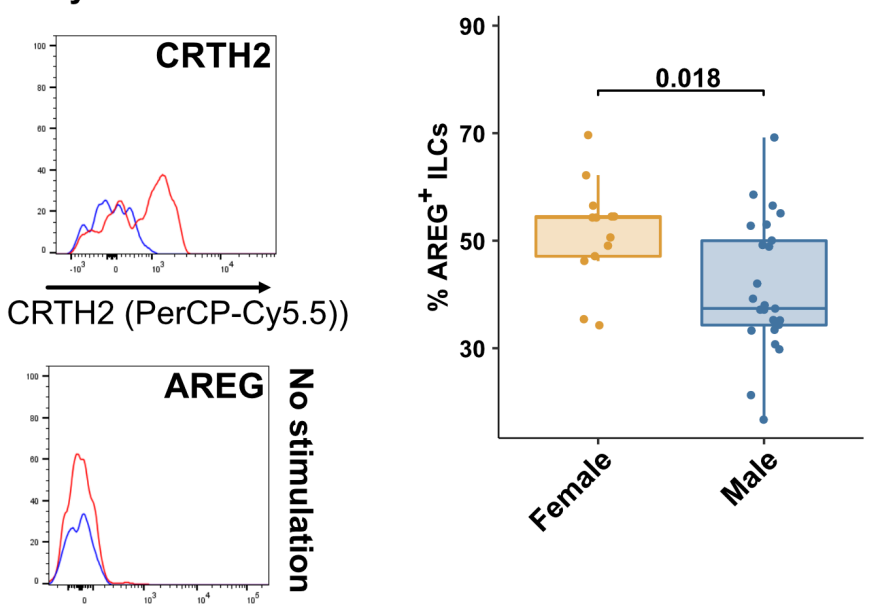

C

\section{0}

521

522

523

524

525

526

527

528

529

530

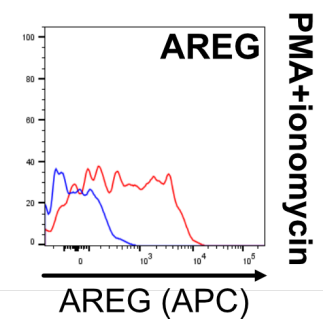
$\operatorname{Lin}^{-} \mathrm{TBX} 21^{-} \mathrm{CD} 127^{+}$.

Fig. 6. Peripheral blood ILCs exhibit homeostatic ILC2 functions

(A-B) Flow cytometry for the indicated proteins. Cells in (A) were assayed at steady-state and cells in (B) were assayed either at steady-state or after stimulation with PMA and ionomycin, as indicated. Detection of surface proteins was performed on ILCs gated as Lin-CD56-CD $^{-} 127^{+}$and detection of intracellular proteins was performed on ILCs gated as

(C) Percent of AREG+ ILCs in blood of control blood donors after stimulation with PMA and ionomycin. Each dot represents an individual blood donor. Boxplots represent the distribution of the data with the center line drawn through the median with the upper and lower bounds of the box at the 75th and 25th percentiles respectively. The upper and lower whiskers extend to the largest or smallest values within $1.5 \mathrm{x}$ the interquartile range (IQR). P-value is from a two-sided, Wilcoxon rank-sum test. 


\section{DISCUSSION}

533 The outcome of SARS-CoV-2 infection ranges from entirely asymptomatic to lethal

534 COVID-19 (Cevik et al., 2021; He et al., 2021; Jones et al., 2021; Lee et al., 2020; Lennon

535 et al., 2020; Ra et al., 2021; Richardson et al., 2020; Yang et al., 2021). Yet, viral load

536 does not reliably discriminate asymptomatic from symptomatic or hospitalized

537 populations (Cevik et al., 2021; Jones et al., 2021; Lee et al., 2020; Lennon et al., 2020;

538 Ra et al., 2021; Yang et al., 2021). In contrast, demographic factors, including increasing

539 age and male sex, predict worse outcome of SARS-CoV-2 infection (Alkhouli et al., 2020;

540 Bunders and Altfeld, 2020; Gupta et al., 2021; Laxminarayan et al., 2020; Mauvais-Jarvis,

541 2020; O’Driscoll et al., 2020; Peckham et al., 2020; Richardson et al., 2020; Scully et al.,

542 2020). These demographic risk factors could be due to sexual dimorphism and changes

543 with aging in composition and function of the human immune system (Darboe et al., 2020;

544 Klein and Flanagan, 2016; Márquez et al., 2020; Patin et al., 2018; Solana et al., 2012).

545 Therefore it is necessary to account for effects of age and sex to determine if there are

546 additional, independent, effects of SARS-CoV-2-associated disease.

This study collected and analyzed 245 blood samples from 177 adult and 58

548 pediatric patients and controls, spanning the ages of 0.7 to 83 years, with approximately

549 equal numbers of males and females. It was therefore possible to characterize the

550 independent effects of age, sex, COVID-19, and MIS-C on blood lymphoid cell

551 populations. After accounting for effects of age and sex, ILCs, but not CD4 ${ }^{+}$or $\mathrm{CD}^{+} \mathrm{T}$

552 cells, were lower in individuals hospitalized with COVID-19 when compared with controls

553 (Table 2 and Fig. 3A,B). Lower numbers of ILCs were also observed in children with

554 COVID-19 (Table 5 and Fig. 4A,B), as well as in an independent cohort of adult patients 
555 (Supplementary Fig. S2). Among adults infected with SARS-CoV-2, lower abundance of

556 ILCs, but not of the other lymphoid cell subsets, was associated with increased odds of

557 hospitalization, longer duration of hospitalization, and higher blood level of factors 558 associated with systemic inflammation, including CRP (Tables 3 and 4, and Fig. 3C). This

559 inverse relationship between ILC abundance and CRP was also evident in children with

560 COVID-19 or MIS-C (Fig. 4C).

The identification of reduced ILC numbers as uniquely related to COVID-19

severity is important as these cells mediate disease tolerance in animal models (Artis and

and Ayres, 2018; Monticelli et al., 2015, 2011). The results here therefore indicate that

loss of ILCs from blood correlates with loss of ILC-associated homeostatic functions,

lymphoid cells, and does not provide direct information about processes occurring within tissues, transcriptional and functional characterization of blood ILCs demonstrated that these cells are similar to ILCs isolated from lung tissue (Fig. 5). Human ILCs circulate in lymphatic fluid draining from the tissues to the blood via the thoracic duct (Buggert et al.,

571 2020), raising the possibility that some ILCs in the blood originate from, or traffic to, lung

572 tissue. Further characterization of these blood ILCs showed that they are functional ILC2s

573 capable of producing the protein AREG (Fig. 6A,B). Given the tissue homeostatic role

574 AREG plays in animal models of disease tolerance (Branzk et al., 2018; Diefenbach et

575 al., 2020; Jamieson et al., 2013; McCarville and Ayres, 2018; Monticelli et al., 2015, 576 2011), the discovery here that males have a smaller fraction than females of blood ILCs

577 capable of producing AREG (Fig. 6C) could explain why males are at greater risk of death 
578 from SARS-CoV-2 infection (O'Driscoll et al., 2020). This sexual dimorphism in ILC

579 function would be amplified further by the lower overall abundance of ILCs in males (Fig.

580 2B and Table 3).

Although the inverse relationship between the number of blood ILCs and severity of COVID-19 suggests that loss of ILC homeostatic function results in breakdown of

583 disease tolerance (Arpaia et al., 2015; Artis and Spits, 2015; Branzk et al., 2018;

584 Diefenbach et al., 2020; McCarville and Ayres, 2018; Monticelli et al., 2015, 2011), this

585 observational study cannot determine whether ILC depletion preceded SARS-CoV-2

586 infection or whether ILC numbers are depleted as a consequence of SARS-CoV-2

587 infection. However, several observations support the hypothesis that individuals with 588 lower ILC numbers at the time of SARS-CoV-2 infection are at greater risk of developing 589 severe disease. ILC numbers in uninfected controls decrease exponentially with age; this 590 decrease is much larger than that seen with other lymphoid cell types (Fig. 2A), and much 591 more closely mirrors the exponential increase in COVID-19 mortality with age (O'Driscoll 592 et al., 2020) (Fig. 2C). In addition, the greater risk of COVID-19 mortality in males 593 (O'Driscoll et al., 2020) correlates with lower abundance of blood ILCs (Fig. 2B and Table 5943 ) and smaller fraction of ILCs capable of producing AREG (Fig. 6C). Further supporting 595 this hypothesis is the observation that conditions independently associated with lower ILC 596 abundance, such as HIV-1 infection (Kløverpris et al., 2016; Wang et al., 2020) and 597 obesity (Brestoff et al., 2015; Yudanin et al., 2019), increase the risk for worse outcomes 598 from SARS-CoV-2 infection (Biccard et al., 2021; Kompaniyets, 2021; Tesoriero et al., 599 2021). 
601 of T cells as well as ILCs (Table 5 and Fig. 4A,B), and longitudinal follow-up samples for 602 pediatric COVID-19 and MIS-C patients showed persistence of low ILC numbers after 603 COVID-19, but normalization of all depleted cell types after recovery from MIS-C (Fig. 604 4D,E and Supplementary Fig. S4). These differences imply that the reversible 605 lymphopenia in MIS-C is due to different underlying processes than the more specific and 606 persistent lower ILC abundance seen in individuals with COVID-19. This difference is 607 made more interesting by the fact that none of the children with MIS-C had required 608 hospitalization for COVID-19 and only one experienced any COVID-19 symptoms. The 609 other children with MIS-C were therefore unaware that they had been infected. It is 610 possible that children with pre-existing lower ILC numbers are at risk of developing

611 COVID-19 if infected with SARS-CoV-2, while other factors such as prolonged exposure 612 to SARS-CoV-2 antigens in the gastrointestinal tract (Yonker et al., 2021), or rare inborn 613 errors of immunity (Sancho-Shimizu et al., 2021), promote inflammatory processes in 614 MIS-C that drive nonspecific lymphoid cell depletion, which ultimately normalizes after 615 recovery.

Although ILC depletion and recovery has been reported in rheumatoid arthritis

617 (Rauber et al., 2017), inflammation-driven ILC-depletion is not necessarily reversible, as 618 ILCs appear permanently depleted after HIV-1 infection, possibly by high levels of 619 common Y-chain cytokines during acute infection (Wang et al., 2020). Better 620 understanding of the processes that drive down ILC abundance in populations 621 susceptible to COVID-19 could potentially allow for development of interventions that 622 increase ILC abundance and restore homeostatic disease tolerance mechanisms. 
624 Spits, 2015; Branzk et al., 2018; Klose and Artis, 2016; Monticelli et al., 2015, 2011) and

625 presumed non-immunologic, host adaptive responses necessary to survive pathogenic

626 infection (López-Otín and Kroemer, 2021; McCarville and Ayres, 2018; Medzhitov et al.,

627 2012; Schneider and Ayres, 2008), the findings reported here support the hypothesis that

628 loss of disease tolerance mechanisms attributable to ILCs increase the risk of morbidity

629 and mortality with SARS-CoV-2 infection. The findings of this observational study warrant

630 establishment of prospective cohorts to determine whether abundance of ILCs or of other

631 Iymphoid cell subsets associated with disease tolerance (Arpaia et al., 2015; Artis and 632 Spits, 2015; Branzk et al., 2018; Diefenbach et al., 2020; McCarville and Ayres, 2018;

633 Monticelli et al., 2015, 2011), predict clinical outcome for infection with SARS-CoV-2 or

634 other lethal pathogens. Understanding the mechanisms that allow an individual to tolerate

635 high-level viral replication without experiencing symptoms, and how these mechanisms

636 can fail and thereby allow for progression to severe disease, will provide the foundation

637 for development of therapeutic interventions that maintain health and improve survival of

638 pathogenic viral infection (Ayres, 2020b). 


\section{Materials and Methods}

649

650

651

652

653

654

655

656

\section{Data availability}

The data that support the findings of this study are available within the manuscript and in its supplementary information files. Bulk RNA-seq datasets generated here can be found at: NCBI Gene Expression Omnibus (GEO): GSE168212. Bulk RNA-seq data generated by previously-published studies are available from NCBI GEO: GSE131031 and GSE126107. This study did not generate unique code. Any additional information required to reanalyze the data reported in this paper is available from the lead contact upon request.

\section{Peripheral blood PBMCs}

As part of a COVID-19 observational study, peripheral blood samples were collected from 91 adults with SARS-CoV-2 infection at the Massachusetts General Hospital and affiliated outpatient clinics. Request for access to coded patient samples was reviewed by the Massachusetts Consortium for Pathogen Readiness (https://masscpr.hms.harvard.edu/), and approved by the University of Massachusetts Medical School IRB (protocol \#H00020836). Pediatric participants with COVID-19 or MIS-C were enrolled in the Massachusetts General Hospital Pediatric COVID-19 Biorepository (MGB IRB \# 2020P000955); healthy pediatric controls were enrolled in the Pediatric Biorepository (MGB IRB \# 2016P000949). Samples were collected after obtaining consent from the patient if 18 years or older, or from the parent/guardian, plus assent when appropriate. Demographic, laboratory, and clinical outcome data were included with the coded samples. Samples from 86 adult blood donors and 17 pediatric blood donors, either 
670 collected prior to the SARS-CoV-2 outbreak, or from healthy individuals screened at a

671 blood bank, were included as controls.

672

Human mononuclear cell isolation

674 Human peripheral blood was diluted in an equal volume of RPMI-1640 (Gibco), overlaid 675 on Lymphoprep (STEMSELL, 07851), and centrifuged at $500 \times \mathrm{g}$ at room temperature for

67630 minutes. Mononuclear cells were washed 3 times with MACS buffer $(0.5 \%$ BSA and 2 677 mM EDTA in PBS) and frozen in FBS containing 10\% DMSO.

678

679

680

681

682

683

684

685

686

687

688

689

690

691

\section{Flow cytometry}

Peripheral blood mononuclear cells (PBMCs) were first stained with Live and Dead violet viability kit (Invitrogen, L-34963). To detect surface molecules, cells were stained in MACS buffer with antibodies (Supplementary Table S8) for $30 \mathrm{~min}$ at $4^{\circ} \mathrm{C}$ in the dark. To detect IL-13 or AREG, cells were stimulated with PMA and ionomycin (eBioscience, 004970-03) for 3 hours with Brefeldin A and Monensin (eBioscience, 00-4980-03) present during the stimulation. To detect transcription factors or cytokines, cells were fixed and permeabilized using Foxp3 staining buffer kit (eBioscience, 00-5523-00), then intracellular molecules were stained in permeabilization buffer with antibodies. Cells were detected on a BD Celesta flow cytometer using previously established gating strategies (Wang et al., 2020). Cell subsets were identified using FlowJo'M software (Becton, Dickson and Company). Representative gating strategies are shown in Fig. S6. 


\section{Bulk RNA-Seq Library preparation of PBMC ILCs}

693 The sequencing libraries were prepared using CEL-Seq2 (Hashimshony et al., 2016).

694 RNA from sorted cells was extracted using TRIzol reagent (ThermoFisher, 15596018).

$69510 \mathrm{ng}$ RNA was used for first strand cDNA synthesis using barcoded primers (the specific 696 primers for each sample were listed in Supplementary Table S9). The second strand was 697 synthesized by NEBNext Second Strand Synthesis Module (NEB, E6111L). The pooled 698 dsDNA was purified with AMPure XP beads (Beckman Coulter, A63880), and subjected 699 to in vitro transcription (IVT) using HiScribe T7 High Yield RNA Synthesis Kit (NEB, 700 E2040S), then treated with ExoSAP-IT (Affymetrix, 78200). IVT RNA was fragmented 701 using RNA fragmentation reagents (Ambion), and underwent another reverse 702 transcription step using random hexamer RT primer-5'-GCC TTG GCA CCC GAG AAT 703 TCC ANN NNN N-3' to incorporate the second adapter. The final library was amplified 704 with indexed primers: RP1 and RPI1 (Supplementary Table S9), and the bead purified 705 library was quantified with 4200 TapeStation (Agilent Technologies), and paired-end 706 sequenced on Nextseq 500 V2 (Illumina), Read 1: 15 cycles; index 1: 6 cycles; Read 2: 70760 cycles.

\section{RNA-seq analyses}

710 Pooled reads from PBMC ILCs were separated by CEL-Seq2 barcodes, and 711 demultiplexed reads from RNA-seq of ILCs from lung (Ardain et al., 2019), spleen and 712 intestine (Yudanin et al., 2019), were downloaded from GSE131031 and GSE126107.

713 Within the DolphinNext RNA-seq pipeline (Revision 4) (Yukselen et al., 2020), reads were 714 aligned to the hg19 genome using STAR (version 2.1.6) (Dobin et al., 2013) and counts 
medRxiv preprint doi: https://doi.org/10.1101/2021.01.14.21249839; this version posted October 11, 2021. The copyright holder for this preprint (which was not certified by peer review) is the author/funder, who has granted medRxiv a license to display the preprint in perpetuity. It is made available under a CC-BY-NC-ND 4.0 International license .

715 of reads aligned to RefSeq genes were quantified using RSEM (version 1.3.1) (Li and

716 Dewey, 2011). Normalized transcript abundance in the form of TPMs were used to filter

717 out low abundance transcripts with an average of $<3$ TPMs across libraries. RSEM718 generated expected counts were normalized and differential analysis was performed

719 using DEseq2 (Love et al., 2014) in R, with significant genes defined as a greater than

720 1.5-fold difference and an adjusted p-value <0.01. GO Enrichment Analysis was

721 performed in $\mathrm{R}$ using the enrichGO function in the clusterProfiler R package (Yu et al.,

722 2012). Data were transformed using vsd within DEseq2 both for the heatmap visualization

723 with ComplexHeatmap (Gu et al., 2016) and for principal component analysis (PCA) with

724 prcomp on the top 250 most variable genes. Normalized counts were generated for 725 plotting using the counts command in Deseq2.

726

\section{Statistical analysis and data visualization}

728 Data were prepared for analysis with tidyverse packages (Wickham et al., 2019) and

729 visualized using the ggplot2 (Wickham, 2016), ggpubr (Kassambara, 2020), and

730 ComplexHeatmap ( $\mathrm{Gu}$ et al., 2016) packages, within the $\mathrm{R}$ computer software

731 environment (version 4.0.2) (R Core Team, 2020). Group differences were determined

732 with pairwise, two-sided, Wilcoxon rank-sum tests, or Fisher's exact test, as indicated,

733 with Bonferroni correction for multiple comparisons. Multiple linear regression analyses

734 were performed with dependent and independent variables as indicated in the text, using

735 the Im function in R. Pairwise group comparisons on estimated marginal means

736 generated from multiple linear regression were performed using the emmeans package

737 (Lenth, 2020) in R, with multiple comparison correction using the Tukey adjustment.

738 Multiple logistic regressions were performed using the glm function in R. Longitudinal 
739 follow-up analyses on pediatric COVID-19 and MIS-C was performed with linear mixed-

740 effect models using Ime4 (Bates et al., 2015) in R with the equation: log2 (lymphoid cell

741 abundance) $\sim$ Age + Sex + Group + Group:Follow_up + (1|Patient_ID). This model tested

742 the effect of followup on ILC abundance in the pediatric COVID-19 and MIS-C groups

743 while accounting for age, sex, and group. Statistical significance was determined with

744 ImerTest (Kuznetsova et al., 2017) in R, using the Satterthwarte's degrees of freedom

745 method. $\mathrm{p}<0.05$ was considered significant. United States SARS-CoV-2 infection and

746 mortality data were downloaded from (CDC Case Surveillance Task Force, 2020) and

747 cases with age group and outcome available were plotted by age group as indicated.

748 Mortality rate was calculated by dividing the number of fatal cases by the total number of

749 cases with known outcome in each age group as indicated. 


\section{REFERENCES}

761 Alghamdi IG, Hussain II, Almalki SS, Alghamdi MS, Alghamdi MM, El-Sheemy MA. 2014.

The pattern of Middle East respiratory syndrome coronavirus in Saudi Arabia: a descriptive epidemiological analysis of data from the Saudi Ministry of Health. Int J Gen Med 7:417.

Alkhouli M, Nanjundappa A, Annie F, Bates MC, Bhatt DL. 2020. Sex Differences in Case 95:1613-1620.

768

769

770

771

772

773

774

775

776

777

778

779

780

781

782

Anegon I, Cuturi MC, Trinchieri G, Perussia B. 1988. Interaction of Fc receptor (CD16) ligands induces transcription of interleukin 2 receptor (CD25) and lymphokine genes and expression of their products in human natural killer cells. J Exp Med $167: 452-472$.

Ardain A, Domingo-Gonzalez R, Das S, Kazer SW, Howard NC, Singh A, Ahmed M, Nhamoyebonde S, Rangel-Moreno J, Ogongo P, Lu L, Ramsuran D, de la Luz Garcia-Hernandez M, K. Ulland T, Darby M, Park E, Karim F, Melocchi L, Madansein R, Dullabh KJ, Dunlap M, Marin-Agudelo N, Ebihara T, Ndung'u T, Kaushal D, Pym AS, Kolls JK, Steyn A, Zúñiga J, Horsnell W, Yokoyama WM, Shalek AK, Kløverpris HN, Colonna M, Leslie A, Khader SA. 2019. Group 3 innate lymphoid cells mediate early protective immunity against tuberculosis. Nature 570:528-532.

Arpaia N, Green JA, Moltedo B, Arvey A, Hemmers S, Yuan S, Treuting PM, Rudensky AY. 2015. A Distinct Function of Regulatory T Cells in Tissue Protection. Cell 162:1078-1089. 
Artis D, Spits H. 2015. The biology of innate lymphoid cells. Nature 517:293-301.

Ayres JS. 2020a. The Biology of Physiological Health. Cell 181:250-269.

Ayres JS. 2020b. Surviving COVID-19: A disease tolerance perspective. Sci Adv 6:eabc1518.

Bates D, Mächler M, Bolker B, Walker S. 2015. Fitting Linear Mixed-Effects Models Usinglme4. Journal of Statistical Software. doi:10.18637/jss.v067.i01 
Elfagieh M, Elhadi M, Huwaysh MA, Yahya MMA, Mohammed AAK, Majeed AAM, A, Lorenzoni C, Mambo J, Isabel Chissaque I, Mouzinho Saide M, Chaibou MS, Mamane M, Amadou F, Adesoji Ademuyiwa AA, Akinyinka Omigbodun AO, Embu H, Nuhu S, Ojiakor S, Nuhu A, Fowotade A, Sanusi A, Osinaike B, Idowu O, Amali AO, Ibrahim S, Adamu AA, Kida I, Otokwala J, Essam M, Alagbe-Briggs O, Ojum S, Fathima Paruk FP, Juan Scribante JS, Mdladla A, Mabotja T, Naidoo R, Matos-Puig R, Ramkillawan A, Smith M, Arnold-Day C, Thomson D, Calligaro G, Joubert I, Jagga J, Piercy J, Michell L, Devenish L, Miller M, Fernandes N, Gopalan D, Pershad S, Grabowski N, Rammego M, Zwane S, Dhlamini ME, Neuhoff M, C, Theron A, Herselman R, Badenhorst J, Moletsane G, Loots H, Paruk F, Chausse J, Neuhoff M, Sebastian M, Grabowski N, Rheeder P, van HougenhouckTulleken W, Snyman C, Adeleke D, Esterhuizen J, de Man L, Mosola M, van der cohort study. Lancet 397:1885-1894. 
828 Branzk N, Gronke K, Diefenbach A. 2018. Innate lymphoid cells, mediators of tissue homeostasis, adaptation and disease tolerance. Immunol Rev 286:86-101.

830 Brestoff JR, Kim BS, Saenz SA, Stine RR, Monticelli LA, Sonnenberg GF, Thome JJ, Farber DL, Lutfy K, Seale P, Artis D. 2015. Group 2 innate lymphoid cells promote beiging of white adipose tissue and limit obesity. Nature 519:242-246.

Buggert M, Vella LA, Nguyen S, Wu VH, Chen Z, Sekine T, Perez-Potti A, Maldini CR, Gorin J-B, Rivera-Ballesteros O, Hertwig L, Antel JP, Johnson ME, Okoye A, Picker L, Vahedi G, Sparrelid E, Llewellyn-Lacey S, Gostick E, Sandberg JK, Björkström N, Bar-Or A, Dori Y, Naji A, Canaday DH, Laufer TM, Wells AD, Price DA, Frank I, Douek DC, Wherry EJ, Itkin MG, Betts MR. 2020. The Identity of Human Tissue-Emigrant CD8+ T Cells. Cell 183:1946-1961.e15.

Bunders MJ, Altfeld M. 2020. Implications of Sex Differences in Immunity for SARS-CoV2 Pathogenesis and Design of Therapeutic Interventions. Immunity 53:487-495.

Califano D, Furuya Y, Roberts S, Avram D, McKenzie ANJ, Metzger DW. 2018. IFN-Y increases susceptibility to influenza A infection through suppression of group II innate lymphoid cells. Mucosal Immunol 11:209-219.

847 Cevik M, Tate M, Lloyd O, Maraolo AE, Schafers J, Ho A. 2021. SARS-CoV-2, SARSCoV, and MERS-CoV viral load dynamics, duration of viral shedding, and infectiousness: a systematic review and meta-analysis. The Lancet Microbe 2:e13-e22. 
851 Channappanavar R, Fett C, Mack M, Ten Eyck PP, Meyerholz DK, Perlman S. 2017. SexBased Differences in Susceptibility to Severe Acute Respiratory Syndrome Coronavirus Infection. J Immunol 198:4046-4053.

Charles Bailey L, Razzaghi H, Burrows EK, Timothy Bunnell H, Camacho PEF, Christakis Across the United States. JAMA Pediatr. doi:10.1001/jamapediatrics.2020.5052

Chen J, Subbarao K. 2007. The Immunobiology of SARS. Annu Rev Immunol 25:443472.

Cherrier DE, Serafini N, Di Santo JP. 2018. Innate Lymphoid Cell Development: A T Cell Perspective. Immunity 48:1091-1103.

Cheung EW, Zachariah P, Gorelik M, Boneparth A, Kernie SG, Orange JS, Milner JD. 2020. Multisystem Inflammatory Syndrome Related to COVID-19 in Previously

870 Cumnock K, Gupta AS, Lissner M, Chevee V, Davis NM, Schneider DS. 2018. Host 1642.e3. 
873 Darboe A, Nielsen CM, Wolf A-S, Wildfire J, Danso E, Sonko B, Bottomley C, Moore SE, Lymphoid Cells in an African Population. Front Immunol 11:594107.

Diefenbach A, Gnafakis S, Shomrat O. 2020. Innate Lymphoid Cell-Epithelial Cell Modules Sustain Intestinal Homeostasis. Immunity 52:452-463.

878

879

880

881

882

883

884

885

886

887

888

889

890 Gingeras TR. 2013. STAR: ultrafast universal RNA-seq aligner. Bioinformatics 29:15-21.

Donnelly CA, Ghani AC, Leung GM, Hedley AJ, Fraser C, Riley S, Abu-Raddad LJ, Ho L-M, Thach T-Q, Chau P, Chan K-P, Lam T-H, Tse L-Y, Tsang T, Liu S-H, Kong JHB, Lau EMC, Ferguson NM, Anderson RM. 2003. Epidemiological determinants of spread of causal agent of severe acute respiratory syndrome in Hong Kong. Lancet 361:1761-1766.

D'Souza SS, Shen X, Fung ITH, Ye L, Kuentzel M, Chittur SV, Furuya Y, Siebel CW, Maillard IP, Metzger DW, Yang Q. 2019. Compartmentalized effects of aging on group 2 innate lymphoid cell development and function. Aging Cell. doi:10.1111/acel.13019

Feldstein LR, Rose EB, Horwitz SM, Collins JP, Newhams MM, Son MBF, Newburger JW, Kleinman LC, Heidemann SM, Martin AA, Singh AR, Li S, Tarquinio KM, Jaggi P, Oster ME, Zackai SP, Gillen J, Ratner AJ, Walsh RF, Fitzgerald JC, Keenaghan MA, Alharash H, Doymaz S, Clouser KN, Giuliano JS Jr, Gupta A, Parker RM, Maddux AB, Havalad V, Ramsingh S, Bukulmez H, Bradford TT, Smith LS, Tenforde MW, Carroll CL, Riggs BJ, Gertz SJ, Daube A, Lansell A, Coronado 
Munoz A, Hobbs CV, Marohn KL, Halasa NB, Patel MM, Randolph AG,

Feldstein LR, Tenforde MW, Friedman KG, Newhams M, Rose EB, Dapul H, Soma VL, Maddux AB, Mourani PM, Bowens C, Maamari M, Hall MW, Riggs BJ, Giuliano JS TC, Loftis LL, Hobbs CV, Halasa NB, Doymaz S, Babbitt CJ, Hume JR, Gertz SJ, Irby K, Clouser KN, Cvijanovich NZ, Bradford TT, Smith LS, Heidemann SM,

Zackai SP, Wellnitz K, Nofziger RA, Horwitz SM, Carroll RW, Rowan CM, Tarquinio KM, Mack EH, Fitzgerald JC, Coates BM, Jackson AM, Young CC, Son MBF, Patel MM, Newburger JW, Randolph AG, Overcoming COVID-19

Flanagan KL, Fink AL, Plebanski M, Klein SL. 2017. Sex and Gender Differences in the Outcomes of Vaccination over the Life Course. Annu Rev Cell Dev Biol 33:577599.

914 Gallo Marin B, Aghagoli G, Lavine K, Yang L, Siff EJ, Chiang SS, Salazar-Mather TP, COVID-19 severity: A literature review. Rev Med Virol e2146. 
composition associates with COVID-19 disease severity. Clinical \& translational immunology 9:e1224.

921 Giefing-Kröll C, Berger P, Lepperdinger G, Grubeck-Loebenstein B. 2015. How sex and age affect immune responses, susceptibility to infections, and response to vaccination. Aging Cell 14:309-321.

Gu Z, Eils R, Schlesner M. 2016. Complex heatmaps reveal patterns and correlations in multidimensional genomic data. Bioinformatics 32:2847-2849.

926 Gupta RK, Harrison EM, Ho A, Docherty AB, Knight SR, van Smeden M, Abubakar I, Lipman M, Quartagno M, Pius R, Buchan I, Carson G, Drake TM, Dunning J, Fairfield CJ, Gamble C, Green CA, Halpin S, Hardwick HE, Holden KA, Horby PW, Jackson C, Mclean KA, Merson L, Nguyen-Van-Tam JS, Norman L, Olliaro PL, Pritchard MG, Russell CD, Scott-Brown J, Shaw CA, Sheikh A, Solomon T, Sudlow C, Swann OV, Turtle L, Openshaw PJM, Baillie JK, Semple MG, Noursadeghi M,

He J, Guo Y, Mao R, Zhang J. 2021. Proportion of asymptomatic coronavirus disease 2019: A systematic review and meta-analysis. J Med Virol 93:820-830.

940 Heald-Sargent T, Muller WJ, Zheng X, Rippe J, Patel AB, Kociolek LK. 2020. Age-Related 

2019 (COVID-19). JAMA Pediatr 174:902-903.

944 Huang C, Wang Y, Li X, Ren L, Zhao J, Hu Y, Zhang L, Fan G, Xu J, Gu X, Cheng Z, Yu T, Xia J, Wei Y, Wu W, Xie X, Yin W, Li H, Liu M, Xiao Y, Gao H, Guo L, Xie J, Wang G, Jiang R, Gao Z, Jin Q, Wang J, Cao B. 2020. Clinical features of patients infected with 2019 novel coronavirus in Wuhan, China. Lancet 395:497-506.

Huang I, Pranata R. 2020. Lymphopenia in severe coronavirus disease-2019 (COVID19): systematic review and meta-analysis. J Intensive Care Med 8:36.

Jamieson AM, Pasman L, Yu S, Gamradt P, Homer RJ, Decker T, Medzhitov R. 2013. Role of tissue protection in lethal respiratory viral-bacterial coinfection. Science

Jhaveri KA, Trammell RA, Toth LA. 2007. Effect of environmental temperature on sleep, locomotor activity, core body temperature and immune responses of C57BL/6J

Jones TC, Biele G, Mühlemann B, Veith T, Schneider J, Beheim-Schwarzbach J, Bleicker T, Tesch J, Schmidt ML, Sander LE, Kurth F, Menzel P, Schwarzer R, Zuchowski M, Hofmann J, Krumbholz A, Stein A, Edelmann A, Corman VM, Drosten C. 2021.

961 Karlberg J. 2004. Do Men Have a Higher Case Fatality Rate of Severe Acute Respiratory Syndrome than Women Do? American Journal of Epidemiology. doi:10.1093/aje/kwh056 Estimating infectiousness throughout SARS-CoV-2 infection course. Science 373:eabi5273. 
965 Klein SL, Flanagan KL. 2016. Sex differences in immune responses. Nat Rev Immunol

$$
\text { 16:626-638. }
$$

Klose CSN, Artis D. 2016. Innate lymphoid cells as regulators of immunity, inflammation and tissue homeostasis. Nat Immunol 17:765-774.

Kløverpris HN, Kazer SW, Mjösberg J, Mabuka JM, Wellmann A, Ndhlovu Z, Yadon MC,

Kompaniyets L. 2021. Body Mass Index and Risk for COVID-19-Related Hospitalization, V, Abdool Karim SS, Goulder P, Shalek AK, Walker BD, Ndung'u T, Leslie A. 2016. Innate Lymphoid Cells Are Depleted Irreversibly during Acute HIV-1 Infection in the Absence of Viral Suppression. Immunity 44:391-405. Intensive Care Unit Admission, Invasive Mechanical Ventilation, and Death United States, March-December 2020. MMWR Morb Mortal Wkly Rep 70. doi:10.15585/mmwr.mm7010e4

Kuri-Cervantes L, Pampena MB, Meng W, Rosenfeld AM, Ittner CAG, Weisman AR, Agyekum RS, Mathew D, Baxter AE, Vella LA, Kuthuru O, Apostolidis SA, Bershaw in linear mixed effects models. J Stat Softw 82:1-26. 
Laxminarayan R, Wahl B, Dudala SR, Gopal K, Mohan B C, Neelima S, Jawahar Reddy KS, Radhakrishnan J, Lewnard JA. 2020. Epidemiology and transmission dynamics of COVID-19 in two Indian states. Science 370:691-697.

Lee S, Kim T, Lee E, Lee C, Kim H, Rhee H, Park SY, Son H-J, Yu S, Park JW, Choo EJ, Park S, Loeb M, Kim TH. 2020. Clinical Course and Molecular Viral Shedding Among Asymptomatic and Symptomatic Patients With SARS-CoV-2 Infection in a Community Treatment Center in the Republic of Korea. JAMA Internal Medicine 180:1447.

Leist SR, Dinnon KH 3rd, Schäfer A, Tse LV, Okuda K, Hou YJ, West A, Edwards CE, Sanders W, Fritch EJ, Gully KL, Scobey T, Brown AJ, Sheahan TP, Moorman NJ, Boucher RC, Gralinski LE, Montgomery SA, Baric RS. 2020. A Mouse-Adapted SARS-CoV-2 Induces Acute Lung Injury and Mortality in Standard Laboratory Mice. Cell 183:1070-1085.e12.

Lennon NJ, Bhattacharyya RP, Mina MJ, Rehm HL, Hung DT, Smole S, Woolley A, Lander ES, Gabriel SB. 2021. Cross-sectional assessment of SARS-CoV-2 viral load by symptom status in Massachusetts congregate living facilities. J Infect Dis. doi:10.1093/infdis/jiab367

Lennon NJ, Bhattacharyya RP, Mina MJ, Rehm HL, Hung DT, Smole S, Woolley A, Lander ES, Gabriel SB. 2020. Comparison of viral levels in individuals with or without symptoms at time of COVID-19 testing among 32,480 residents and staff of nursing homes and assisted living facilities in Massachusetts. bioRxiv. doi:10.1101/2020.07.20.20157792

Lenth R. 2020. emmeans: Estimated Marginal Means, aka Least-Squares Means. 
1011

1012

1013

1014

1015

1016

1017

1018

1019

1020

1021

1022

1023

1024

1025

1026

1027

1028

1029

1030

1031

1032

1033

Li B, Dewey CN. 2011. RSEM: accurate transcript quantification from RNA-Seq data with or without a reference genome. BMC Bioinformatics 12:323.

Li B, Zhang S, Zhang R, Chen X, Wang Y, Zhu C. 2020. Epidemiological and Clinical Characteristics of COVID-19 in Children: A Systematic Review and Meta-Analysis. Front Pediatr 8:591132.

Licciardi F, Pruccoli G, Denina M, Parodi E, Taglietto M, Rosati S, Montin D. 2020. SARSCoV-2-Induced Kawasaki-Like Hyperinflammatory Syndrome: A Novel COVID Phenotype in Children. Pediatrics. doi:10.1542/peds.2020-1711

López-Otín C, Kroemer G. 2021. Hallmarks of Health. Cell 184:33-63.

LoTempio JE, Billings EA, Draper K, Ralph C, Moshgriz M, Duong N, Bard JD, Gai X, Wessel D, DeBiasi RL, Campos JM, Vilain E, Delaney M, Michael DG. 2021. Novel SARS-CoV-2 spike variant identified through viral genome sequencing of the pediatric Washington D.C. COVID-19 outbreak. medRxiv 2021.02.08.21251344.

Love M, Anders S, Huber W. 2014. Differential analysis of count data--the DESeq2 package. Genome Biol 15:550.

Lu X, Zhang L, Du H, Zhang J, Li YY, Qu J, Zhang W, Wang Y, Bao S, Li Y, Wu C, Liu H, Liu D, Shao J, Peng X, Yang Y, Liu Z, Xiang Y, Zhang F, Silva RM, Pinkerton KE, Shen K, Xiao H, Xu S, Wong GWK, Chinese Pediatric Novel Coronavirus Study Team. 2020. SARS-CoV-2 Infection in Children. N Engl J Med 382:1663-1665.

Lucas C, Wong P, Klein J, Castro TBR, Silva J, Sundaram M, Ellingson MK, Mao T, Oh JE, Israelow B, Takahashi T, Tokuyama M, Lu P, Venkataraman A, Park A, Mohanty S, Wang H, Wyllie AL, Vogels CBF, Earnest R, Lapidus S, Ott IM, Moore AJ, Muenker MC, Fournier JB, Campbell M, Odio CD, Casanovas-Massana A, 
1034

1035

1036

1037

1038

1039

1040

1041

1042

1043

1044

1045

1046

1047

1048

1049

1050

1051

1052

1053

1054

1055

1056

Yale IMPACT Team, Herbst R, Shaw AC, Medzhitov R, Schulz WL, Grubaugh ND, Dela Cruz C, Farhadian S, Ko Al, Omer SB, Iwasaki A. 2020. Longitudinal analyses reveal immunological misfiring in severe COVID-19. Nature 584:463469.

Luo X, Zhou W, Yan X, Guo T, Wang B, Xia H, Ye L, Xiong J, Jiang Z, Liu Y, Zhang B, Yang W. 2020. Prognostic Value of C-Reactive Protein in Patients With Coronavirus 2019. Clin Infect Dis 71:2174-2179.

Márquez EJ, Chung C-H, Marches R, Rossi RJ, Nehar-Belaid D, Eroglu A, Mellert DJ, Kuchel GA, Banchereau J, Ucar D. 2020. Sexual-dimorphism in human immune system aging. Nat Commun 11:751.

Mathew D, Giles JR, Baxter AE, Oldridge DA, Greenplate AR, Wu JE, Alanio C, KuriCervantes L, Pampena MB, D’Andrea K, Manne S, Chen Z, Huang YJ, Reilly JP, Weisman AR, Ittner CAG, Kuthuru O, Dougherty J, Nzingha K, Han N, Kim J, Pattekar A, Goodwin EC, Anderson EM, Weirick ME, Gouma S, Arevalo CP, Bolton MJ, Chen F, Lacey SF, Ramage H, Cherry S, Hensley SE, Apostolidis SA, Huang AC, Vella LA, UPenn COVID Processing Unit, Betts MR, Meyer NJ, Wherry EJ. 2020. Deep immune profiling of COVID-19 patients reveals distinct immunotypes with therapeutic implications. Science 369. doi:10.1126/science.abc8511

Mauvais-Jarvis F. 2020. Aging, Male Sex, Obesity, and Metabolic Inflammation Create the Perfect Storm for COVID-19. Diabetes 69:1857-1863.

McCarville JL, Ayres JS. 2018. Disease tolerance: concept and mechanisms. Curr Opin Immunol 50:88-93. 
Medzhitov R, Schneider DS, Soares MP. 2012. Disease tolerance as a defense strategy. Science 335:936-941.

Monticelli LA, Osborne LC, Noti M, Tran SV, Zaiss DMW, Artis D. 2015. IL-33 promotes an innate immune pathway of intestinal tissue protection dependent on amphiregulin-EGFR interactions. Proc Natl Acad Sci U S A 112:10762-10767.

Monticelli LA, Sonnenberg GF, Abt MC, Alenghat T, Ziegler CGK, Doering TA, Angelosanto JM, Laidlaw BJ, Yang CY, Sathaliyawala T, Kubota M, Turner D, Diamond JM, Goldrath AW, Farber DL, Collman RG, Wherry EJ, Artis D. 2011. Innate lymphoid cells promote lung-tissue homeostasis after infection with influenza virus. Nat Immunol 12:1045-1054.

Mudd PA, Crawford JC, Turner JS, Souquette A, Reynolds D, Bender D, Bosanquet JP, Anand NJ, Striker DA, Martin RS, Boon ACM, House SL, Remy KE, Hotchkiss RS, Presti RM, O’Halloran JA, Powderly WG, Thomas PG, Ellebedy AH. 2020. Distinct inflammatory profiles distinguish COVID-19 from influenza with limited contributions from cytokine storm. Sci Adv 6. doi:10.1126/sciadv.abe3024

O'Driscoll M, Ribeiro Dos Santos G, Wang L, Cummings DAT, Azman AS, Paireau J, Fontanet A, Cauchemez S, Salje H. 2020. Age-specific mortality and immunity patterns of SARS-CoV-2. Nature. doi:10.1038/s41586-020-2918-0

Patin E, Hasan M, Bergstedt J, Rouilly V, Libri V, Urrutia A, Alanio C, Scepanovic P, Hammer C, Jönsson F, Beitz B, Quach H, Lim YW, Hunkapiller J, Zepeda M, Green C, Piasecka B, Leloup C, Rogge L, Huetz F, Peguillet I, Lantz O, Fontes M, Di Santo JP, Thomas S, Fellay J, Duffy D, Quintana-Murci L, Albert ML, Milieu 
1079

1080

1081

1082

1083

1084

1085

1086

1087

1088

1089

1090

1091

1092

1093

1094

1095

1096

1097

1098

1099

1100
Intérieur Consortium. 2018. Natural variation in the parameters of innate immune cells is preferentially driven by genetic factors. Nat Immunol 19:302-314.

Peckham H, de Gruijter NM, Raine C, Radziszewska A, Ciurtin C, Wedderburn LR, Rosser EC, Webb K, Deakin CT. 2020. Male sex identified by global COVID-19 meta-analysis as a risk factor for death and ITU admission. Nature Communications 11:6317.

Piasecka B, Duffy D, Urrutia A, Quach H, Patin E, Posseme C, Bergstedt J, Charbit B, Rouilly V, MacPherson CR, Hasan M, Albaud B, Gentien D, Fellay J, Albert ML, Quintana-Murci L, Milieu Intérieur Consortium. 2018. Distinctive roles of age, sex, and genetics in shaping transcriptional variation of human immune responses to microbial challenges. Proc Natl Acad Sci U S A 115:E488-E497.

Poline J, Gaschignard J, Leblanc C, Madhi F, Foucaud E, Nattes E, Faye A, Bonacorsi S, Mariani P, Varon E, Smati-Lafarge M, Caseris M, Basmaci R, Lachaume N, Ouldali N. 2020. Systematic SARS-CoV-2 screening at hospital admission in children:a French prospective multicenter study. Clin Infect Dis. doi:10.1093/cid/ciaa1044

R Core Team. 2020. R: A Language and Environment for Statistical Computing.

Ra SH, Lim JS, Kim G-U, Kim MJ, Jung J, Kim S-H. 2021. Upper respiratory viral load in asymptomatic individuals and mildly symptomatic patients with SARS-CoV-2 infection. Thorax 76:61-63.

Råberg L, Sim D, Read AF. 2007. Disentangling genetic variation for resistance and tolerance to infectious diseases in animals. Science $318: 812-814$. 
1101 Rak GD, Osborne LC, Siracusa MC, Kim BS, Wang K, Bayat A, Artis D, Volk SW. 2016. Healing. J Invest Dermatol 136:487-496.

Rauber S, Luber M, Weber S, Maul L, Soare A, Wohlfahrt T, Lin N-Y, Dietel K, Bozec A,

Richardson S, Hirsch JS, Narasimhan M, Crawford JM, McGinn T, Davidson KW, the Northwell COVID-19 Research Consortium, Barnaby DP, Becker LB, Chelico JD, Cohen SL, Cookingham J, Coppa K, Diefenbach MA, Dominello AJ, Duer-Hefele J, Falzon L, Gitlin J, Hajizadeh N, Harvin TG, Hirschwerk DA, Kim EJ, Kozel ZM, Marrast LM, Mogavero JN, Osorio GA, Qiu M, Zanos TP. 2020. Presenting Characteristics, Comorbidities, and Outcomes Among 5700 Patients Hospitalized With COVID-19 in the New York City Area. JAMA 323:2052-2059.

Riphagen S, Gomez X, Gonzalez-Martinez C, Wilkinson N, Theocharis P. 2020. Hyperinflammatory shock in children during COVID-19 pandemic. Lancet.

Sanchez KK, Chen GY, Schieber AMP, Redford SE, Shokhirev MN, Leblanc M, Lee YM, Ayres JS. 2018. Cooperative Metabolic Adaptations in the Host Can Favor Asymptomatic Infection and Select for Attenuated Virulence in an Enteric Pathogen. Cell 175:146-158.e15.

Sancho-Shimizu V, Brodin P, Cobat A, Biggs CM, Toubiana J, Lucas CL, Henrickson SE, Belot A, MIS-C@CHGE, Tangye SG, Milner JD, Levin M, Abel L, Bogunovic D, 
Casanova J-L, Zhang S-Y. 2021. SARS-CoV-2-related MIS-C: A key to the viral and genetic causes of Kawasaki disease? J Exp Med 218. doi:10.1084/jem.20210446

Schneider DS, Ayres JS. 2008. Two ways to survive infection: what resistance and tolerance can teach us about treating infectious diseases. Nature Reviews Immunology 8:889-895.

Scully EP, Haverfield J, Ursin RL, Tannenbaum C, Klein SL. 2020. Considering how biological sex impacts immune responses and COVID-19 outcomes. Nat Rev Immunol 20:442-447.

Solana R, Tarazona R, Gayoso I, Lesur O, Dupuis G, Fulop T. 2012. Innate immunosenescence: effect of aging on cells and receptors of the innate immune system in humans. Semin Immunol 24:331-341.

Tesoriero JM, Swain C-AE, Pierce JL, Zamboni L, Wu M, Holtgrave DR, Gonzalez CJ, Udo T, Morne JE, Hart-Malloy R, Rajulu DT, Leung S-YJ, Rosenberg ES. 2021. COVID-19 Outcomes Among Persons Living With or Without Diagnosed HIV Infection in New York State. JAMA Netw Open 4:e2037069.

Verdoni L, Mazza A, Gervasoni A, Martelli L, Ruggeri M, Ciuffreda M, Bonanomi E, D’Antiga L. 2020. An outbreak of severe Kawasaki-like disease at the Italian epicentre of the SARS-CoV-2 epidemic: an observational cohort study. Lancet 395:1771-1778.

Vivier E, Artis D, Colonna M, Diefenbach A, Di Santo JP, Eberl G, Koyasu S, Locksley RM, McKenzie ANJ, Mebius RE, Powrie F, Spits H. 2018. Innate Lymphoid Cells: 10 Years On. Cell 174:1054-1066. 
1147 Wang A, Huen SC, Luan HH, Yu S, Zhang C, Gallezot J-D, Booth CJ, Medzhitov R. 2016. Opposing Effects of Fasting Metabolism on Tissue Tolerance in Bacterial and Viral Inflammation. Cell 166:1512-1525.e12.

Wang Y, Lifshitz L, Gellatly K, Vinton CL, Busman-Sahay K, McCauley S, Vangala P, Kim

Whittaker E, Bamford A, Kenny J, Kaforou M, Jones CE, Shah P, Ramnarayan P, Fraisse K, Derr A, Jaiswal S, Kucukural A, McDonel P, Hunt PW, Greenough T, Houghton J, Somsouk M, Estes JD, Brenchley JM, Garber M, Deeks SG, Luban J. 2020. HIV-1-induced cytokines deplete homeostatic innate lymphoid cells and expand TCF7-dependent memory NK cells. Nat Immunol 21:274-286.

A, Miller O, Davies P, Kucera F, Brierley J, McDougall M, Carter M, Tremoulet A, Shimizu C, Herberg J, Burns JC, Lyall H, Levin M, PIMS-TS Study Group and EUCLIDS and PERFORM Consortia. 2020. Clinical Characteristics of 58 Children With a Pediatric Inflammatory Multisystem Syndrome Temporally Associated With SARS-CoV-2. JAMA 324:259-269.

Wickham H. 2016. ggplot2: Elegant Graphics for Data Analysis. Springer.

Wickham H, Averick M, Bryan J, Chang W, McGowan L, François R, Grolemund G, Hayes A, Henry L, Hester J, Kuhn M, Pedersen T, Miller E, Bache S, Müller K, Ooms J, Robinson D, Seidel D, Spinu V, Takahashi K, Vaughan D, Wilke C, Woo K, Yutani H. 2019. Welcome to the Tidyverse. JOSS 4:1686.

Yang Q, Monticelli LA, Saenz SA, Chi AW-S, Sonnenberg GF, Tang J, De Obaldia ME, Bailis W, Bryson JL, Toscano K, Huang J, Haczku A, Pear WS, Artis D, Bhandoola A. 2013. T cell factor 1 is required for group 2 innate lymphoid cell generation. Immunity 38:694-704. 
1170

1171

1172

1173

1174

1175

1176

1177

1178

1179

1180

1181

1182

1183

1184

1185

1186

1187

1188

1189

1190

1191

Yang Q, Saldi TK, Gonzales PK, Lasda E, Decker CJ, Tat KL, Fink MR, Hager CR, Davis JC, Ozeroff CD, Muhlrad D, Clark SK, Fattor WT, Meyerson NR, Paige CL, Gilchrist AR, Barbachano-Guerrero A, Worden-Sapper ER, Wu SS, Brisson GR, McQueen MB, Dowell RD, Leinwand L, Parker R, Sawyer SL. 2021. Just 2\% of SARS-CoV-2-positive individuals carry $90 \%$ of the virus circulating in communities. Proc Natl Acad Sci U S A 118. doi:10.1073/pnas.2104547118

Yonker LM, Gilboa T, Ogata AF, Senussi Y, Lazarovits R, Boribong BP, Bartsch YC, Loiselle M, Noval Rivas M, Porritt RA, Lima R, Davis JP, Farkas EJ, Burns MD, Young N, Mahajan VS, Hajizadeh S, Herrera Lopez XI, Kreuzer J, Morris R, Martinez EE, Han I, Griswold K Jr, Barry NC, Thompson DB, Church G, Edlow AG, Haas W, Pillai S, Arditi M, Alter G, Walt DR, Fasano A. 2021. Multisystem inflammatory syndrome in children is driven by zonulin-dependent loss of gut mucosal barrier. J Clin Invest. doi:10.1172/JCI149633

Yonker LM, Neilan AM, Bartsch Y, Patel AB, Regan J, Arya P, Gootkind E, Park G, Hardcastle M, St John A, Appleman L, Chiu ML, Fialkowski A, De la Flor D, Lima R, Bordt EA, Yockey LJ, D'Avino P, Fischinger S, Shui JE, Lerou PH, Bonventre JV, Yu XG, Ryan ET, Bassett IV, Irimia D, Edlow AG, Alter G, Li JZ, Fasano A. 2020. Pediatric Severe Acute Respiratory Syndrome Coronavirus 2 (SARS-CoV2): Clinical Presentation, Infectivity, and Immune Responses. J Pediatr 227:4552.e5.

Yu G, Wang L-G, Han Y, He Q-Y. 2012. clusterProfiler: an R Package for Comparing Biological Themes Among Gene Clusters. OMICS 16:284-287. 
1192

1193

1194

1195

1196

1197

1198

1199

1200

1201

1202

1203

1204

1205

1206

1207

1208

1209

1210

1211

1212

1213

1214

Yudanin NA, Schmitz F, Flamar A-L, Thome JJC, Tait Wojno E, Moeller JB, Schirmer M, Latorre IJ, Xavier RJ, Farber DL, Monticelli LA, Artis D. 2019. Spatial and Temporal Mapping of Human Innate Lymphoid Cells Reveals Elements of Tissue Specificity. Immunity 50:505-519.e4.

Yukselen O, Turkyilmaz O, Ozturk AR, Garber M, Kucukural A. 2020. DolphinNext: a distributed data processing platform for high throughput genomics. BMC Genomics 21:310.

Zhang Z-L, Hou Y-L, Li D-T, Li F-Z. 2020. Laboratory findings of COVID-19: a systematic review and meta-analysis. Scand J Clin Lab Invest 80:441-447.

Zhao Q, Meng M, Kumar R, Wu Y, Huang J, Deng Y, Weng Z, Yang L. 2020. Lymphopenia is associated with severe coronavirus disease 2019 (COVID-19) infections: A systemic review and meta-analysis. Int J Infect Dis 96:131-135.

Zheng M, Gao Y, Wang G, Song G, Liu S, Sun D, Xu Y, Tian Z. 2020. Functional exhaustion of antiviral lymphocytes in COVID-19 patients. Cell Mol Immunol.

Zhou F, Yu T, Du R, Fan G, Liu Y, Liu Z, Xiang J, Wang Y, Song B, Gu X, Guan L, Wei Y, Li H, Wu X, Xu J, Tu S, Zhang Y, Chen H, Cao B. 2020. Clinical course and risk factors for mortality of adult inpatients with COVID-19 in Wuhan, China: a retrospective cohort study. Lancet 395:1054-1062. 


\section{ACKNOWLEDGEMENTS}

1216 We thank the Massachusetts Consortium for Pathogen Readiness Specimen Collection

1217 and Processing Team listed below and members of the Yu and Luban Labs. This work

1218 was supported in part by the Massachusetts Consortium for Pathogen Readiness through

1219 grants from the Evergrande Fund and NIH grants R37AI147868 and R01AI148784 to J.L.

1220 and Ruth L. Kirschstein NRSA Fellowship F30HD100110 to N.J.S. The MGH/MassCPR

1221 COVID biorepository was supported by a gift from Ms. Enid Schwartz, by the Mark and

1222 Lisa Schwartz Foundation, the Massachusetts Consortium for Pathogen Readiness, and

1223 the Ragon Institute of MGH, MIT and Harvard. The Pediatric COVID-19 Biorepository was

1224 supported by the National Heart, Lung, and Blood Institute (5K08HL143183 to LMY), and

1225 the Department of Pediatrics at Massachusetts General Hospital for Children (to LMY).

1226

MGH COVID-19 Collection \& Processing Team participants Collection Team:

1228 Kendall Lavin-Parsons ${ }^{1}$, Blair Parry ${ }^{1}$, Brendan Lilley ${ }^{1}$, Carl Lodenstein ${ }^{1}$, Brenna McKaig ${ }^{1}$,

1229 Nicole Charland ${ }^{1}$, Hargun Khanna ${ }^{1}$, Justin Margolin ${ }^{1}$

1230 Processing Team: Anna Gonye ${ }^{2}$, Irena Gushterova², Tom Lasalle ${ }^{2}$, Nihaarika Sharma²,

1231 Brian C. Russo ${ }^{3}$, Maricarmen Rojas-Lopez ${ }^{3}$, Moshe Sade-Feldman ${ }^{4}$, Kasidet

1232 Manakongtreecheep ${ }^{4}$, Jessica Tantivit ${ }^{4}$, Molly Fisher Thomas ${ }^{4}$

1233 Massachusetts Consortium on Pathogen Readiness: Betelihem A. Abayneh ${ }^{5}$, Patrick 1234 Allen $^{5}$, Diane Antille ${ }^{5}$, Katrina Armstrong ${ }^{5}$, Siobhan Boyce ${ }^{5}$, Joan Braley ${ }^{5}$, Karen Branch ${ }^{5}$, 1235 Katherine Broderick ${ }^{5}$, Julia Carney ${ }^{5}$, Andrew Chan $^{5}$, Susan Davidson ${ }^{5}$, Michael Dougan $^{5}$, 1236 David Drew ${ }^{5}$, Ashley Elliman ${ }^{5}$, Keith Flaherty ${ }^{5}$, Jeanne Flannery ${ }^{5}$, Pamela Forde ${ }^{5}$, Elise 1237 Gettings $^{5}$, Amanda Griffin ${ }^{5}$, Sheila Grimmel ${ }^{5}$, Kathleen Grinke ${ }^{5}$, Kathryn Hall ${ }^{5}$, Meg 
1238 Healy ${ }^{5}$, Deborah Henault ${ }^{5}$, Grace Holland ${ }^{5}$, Chantal Kayitesi ${ }^{5}$, Vlasta LaValle ${ }^{5}$, Yuting Lu ${ }^{5}$,

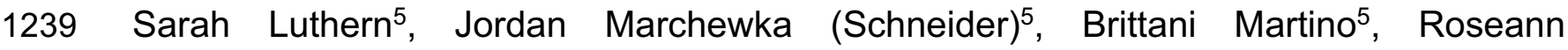

1240 McNamara $^{5}$, Christian Nambu ${ }^{5}$, Susan Nelson ${ }^{5}$, Marjorie Noone $^{5}$, Christine Ommerborn $^{5}$,

1241 Lois Chris Pacheco ${ }^{5}$, Nicole Phan ${ }^{5}$, Falisha A. Porto ${ }^{5}$, Edward Ryan ${ }^{5}$, Kathleen Selleck ${ }^{5}$,

1242 Sue Slaughenhaupt ${ }^{5}$, Kimberly Smith Sheppard ${ }^{5}$, Elizabeth Suschana ${ }^{5}$, Vivine Wilson ${ }^{5}$,

1243 Galit Alter ${ }^{6}$, Alejandro Balazs ${ }^{6}$, Julia Bals ${ }^{6}$, Max Barbash $^{6}$, Yannic Bartsch ${ }^{6}$, Julie

1244 Boucau $^{6}$, Josh Chevalier ${ }^{6}$, Fatema Chowdhury ${ }^{6}$, Kevin Einkauf ${ }^{6}$, Jon Fallon ${ }^{6}$, Liz Fedirko ${ }^{6}$,

1245 Kelsey Finn ${ }^{6}$, Pilar Garcia-Broncano ${ }^{6}$, Ciputra Hartana ${ }^{6}$, Chenyang Jiang ${ }^{6}$, Paulina

1246 Kaplonek $^{6}$, Marshall Karpell ${ }^{6}$, Evan C. Lam ${ }^{6}$, Kristina Lefteri ${ }^{6}$, Xiaodong Lian ${ }^{6}$, Mathias

1247 Lichterfeld ${ }^{6}$, Daniel Lingwood ${ }^{6}$, Hang Liu ${ }^{6}$, Jinqing Liu', Natasha Ly ${ }^{6}$, Ashlin Michell ${ }^{6}$, Ilan

1248 Millstrom $^{6}$, Noah Miranda ${ }^{6}$, Claire O'Callaghan ${ }^{6}$, Matthew Osborn $^{6}$, Shiv Pillai ${ }^{6}$, Yelizaveta

1249 Rassadkina $^{6}$, Alexandra Reissis ${ }^{6}$, Francis Ruzicka ${ }^{6}$, Kyra Seiger $^{6}$, Libera Sessa ${ }^{6}$,

1250 Christianne Sharr ${ }^{6}$, Sally Shin ${ }^{6}$, Nishant Singh ${ }^{6}$, Weiwei Sun ${ }^{6}$, Xiaoming Sun ${ }^{6}$, Hannah

1251 Ticheli $^{6}$, Alicja Trocha-Piechocka ${ }^{6}$, Daniel Worrall ${ }^{6}$, Alex Zhu6 ${ }^{6}$, George Daley ${ }^{7}$, David

1252 Golan $^{7}$, Howard Heller ${ }^{7}$, Arlene Sharpe ${ }^{7}$, Nikolaus Jilg $^{8}$, Alex Rosenthal ${ }^{8}$, Colline Wong ${ }^{8}$ 1253

$1254{ }^{1}$ Department of Emergency Medicine, Massachusetts General Hospital, Boston, MA, 1255 USA.

$1256{ }^{2}$ Massachusetts General Hospital Cancer Center, Boston, MA, USA.

$1257{ }^{3}$ Division of Infectious Diseases, Department of Medicine, Massachusetts General 1258 Hospital, Boston, MA, USA.

$1259{ }^{4}$ Massachusetts General Hospital Center for Immunology and Inflammatory Diseases, 1260 Boston, MA, USA. 
medRxiv preprint doi: https://doi.org/10.1101/2021.01.14.21249839; this version posted October 11, 2021. The copyright holder for this preprint (which was not certified by peer review) is the author/funder, who has granted medRxiv a license to display the preprint in perpetuity. It is made available under a CC-BY-NC-ND 4.0 International license.

$1261{ }^{5}$ Massachusetts General Hospital, Boston, MA, USA.

$1262{ }^{6}$ Ragon Institute of MGH, MIT and Harvard, Cambridge, MA, USA.

$1263{ }^{7}$ Harvard Medical School, Boston, MA, USA.

1264 'BBrigham and Women's Hospital, Boston, MA, USA.

1265

1266 Author information

1267 Correspondence and requests for materials should be addressed to J.L.

1268 (jeremy.luban@umassmed.edu). 